Foss. Rec., 20, 173-199, 2017

https://doi.org/10.5194/fr-20-173-2017

(C) Author(s) 2017. This work is distributed under

the Creative Commons Attribution 3.0 License.

\title{
Classical and new bioerosion trace fossils in Cretaceous belemnite guards characterised via micro-CT
}

\author{
Max Wisshak ${ }^{1}$, Jürgen Titschack ${ }^{1,2}$, Wolf-Achim Kahl ${ }^{3}$, and Peter Girod ${ }^{4}$ \\ ${ }^{1}$ Senckenberg am Meer, Marine Research Department, 26382 Wilhelmshaven, Germany \\ ${ }^{2}$ MARUM - Center for Marine Environmental Sciences, 28359 Bremen, Germany \\ ${ }^{3}$ Bremen University, Geosciences, 28359 Bremen, Germany \\ ${ }^{4}$ Holteistraße 2, 10245 Berlin, Germany \\ Correspondence to: Max Wisshak (max.wisshak@senckenberg.de)
}

Received: 3 April 2017 - Revised: 17 May 2017 - Accepted: 5 June 2017 - Published: 17 July 2017

\begin{abstract}
The ongoing technical revolution in nondestructive 3-D visualisation via micro-computed tomography (micro-CT) finds a valuable application in the studies of bioerosion trace fossils, since their three-dimensional architecture is hidden within hard substrates. This technique, in concert with advanced segmentation algorithms, allows a detailed visualisation and targeted morphometric analyses even of those bioerosion traces that are otherwise inaccessible to the widely applied cast-embedding technique, because they either are filled with lithified sediment or cement or are preserved in inherently insoluble or silicified host substrates, or because they are established type material and should not be altered.

In the present contribution selected examples of such cases are illustrated by reference to bioerosion trace fossils preserved in Late Cretaceous belemnite guards from the European Chalk Province. These case studies comprise an analysis of a diverse ichno-assemblage found associated with the lectotype of the microboring Dendrina dendrina (Morris, 1851) in a belemnite from the upper Campanian to lower Maastrichtian chalk of Norfolk, England, and the description of two new bioerosion trace fossils with type specimens found in belemnite guards from the lower Campanian limestones of Höver, Germany. The latter are Lapispecus hastatus isp. n., a tubular and occasionally branched macroboring for which a sipunculan or a phoronid trace maker are discussed, and Entobia colaria isp. n., a camerate network formed by an excavating sponge that eroded diagnostic grated apertures at the locations of the presumed inhalant papillae or exhaling pores, adding to or replacing filtering devices that are otherwise made of tissue and spicules.
\end{abstract}

As an added value to the non-destructive visualisation procedure, the processed X-ray micro-CT scans of the studied type material provide 3-D models that may now serve as digitypes that can be studied as digital facsimile without the necessity of consulting the actual type specimens.

\section{Introduction}

X-ray computed tomography (CT) and especially microcomputed tomography (micro-CT) have now been firmly established in many fields of earth sciences, including palaeontology, where they have demonstrated their fidelity as nondestructive methods that are about to revolutionise 3-D visualisation of fossils (for a review, see Cunningham et al., 2014). This includes trace fossils, and particularly bioerosion trace fossils (Tapanila, 2008; Beuck et al., 2007, 2008; Amon et al., 2015; Färber et al., 2016). It may be said, however, that micro-CT still remains a relatively expensive and time-consuming method that requires a high level of technical skills. Hence, in the case of bioerosion trace fossils, the approved vacuum cast-embedding technique and consecutive scanning electron microscopy (SEM) visualisation (Golubic et al., 1970; for a review, see Wisshak, 2012) will certainly remain the more widely applied technique for years to come. However, there are cases that do not allow application of the latter, e.g. (i) borings that are filled with lithified sediment or cement, (ii) borings preserved in host substrates that are inherently insoluble or became insoluble due to silicification, or (iii) specimens that should not be altered since they were designated as type material. In the present contribu- 
tion, three examples of combinations of these cases are given, and the value of X-ray micro-CT combined with algorithmbased segmentation is underpinned for these kinds of analyses. The first case study concerns a now classic belemnite rostrum from the Upper Cretaceous chalk of Norfolk, England, published by Morris (1851), that contains a diverse bioerosion trace fossil assemblage, inclusive of the lectotype of Dendrina dendrina (Morris, 1851). The second example concerns two belemnite guards from the lower Campanian limestones of Höver, Germany, that contain the types for the new bioerosion trace fossil Lapispecus hastatus isp. n., for which a sipunculan or a phoronid worm is being discussed as potential trace maker. Finally, a third example deals with another belemnite guard from the same stratigraphic level that bears the holotype of a new sponge boring, Entobia colaria isp. $\mathrm{n}$.

At least three terms have been proposed to address digital visualisation of type material, namely, in chronological order, the so-called "e-type" sensu Gewin (2002), the "digitype" sensu Adams et al. (2010), and the "cybertype" sensu Faulwetter et al. (2013). Whereas the e-type is considered, very generally, a digital image of a holotype and a cybertype addresses all sorts of digital information related to the description of a new taxon, the digitype refers to a digital facsimile of a primary type, i.e. the digital equivalent of a plastotype sensu Morningstar (1924; any artificial specimen moulded and cast directly from the primary type). By coincidence, the term digitype was proposed in the context of an ichnological study (Adams et al., 2010), namely a 3-D laser scan of the dinosaur trackway Eubrontes (?) glenrosensis Shuler, 1935. It is also the term that most adequately describes the applications presented herein, where 3-D models generated from micro-CT scans serve as digitypes of the bioerosion trace fossils of which the actual primary types remain intact in the original host substrates. These digitypes provide taxonomic information that cannot be deduced from a visual inspection of the physical type material alone and may now be viewed and analysed even without the necessity of consulting the actual type specimens. Furthermore, 3-D replicas at any magnification can easily be produced by a 3$\mathrm{D}$ printer, thereby indirectly producing plastotypes. At the time of this writing, both "types of types" are not acknowledged by the International Code of Zoological Nomenclature (ICZN, 1999), but owing to the growing field of "cybertaxonomy", the code might eventually have to implement rules to address such virtual type-relevant material (Faulwetter et al., 2013; Matsuyama et al., 2015). Also, although there is a multitude of options regarding how to present and to archive the 3-D data in the public domain (e.g. Ruthensteiner and $\mathrm{He}$, 2008; Cunningham et al., 2014; Lautenschlager and Rücklin, 2014), at present there still is the need for satisfactory and sustainable formats. Most recently, this issue was reviewed by Davies et al. (2017), who put forward a set of principles for best practice in digital data publication, alongside recommendations concerning the types and formats of data files.

\section{Material and methods}

Overview images of the belemnite guards were produced in transmission or reflected light with a DSLR (Nikon D700 and AF-S Micro NIKKOR $60 \mathrm{~mm}$ 1:2.8 G ED), and closeups with a Keyence VHX-2000D digital microscope and Keyence image analysis application, allowing for Z-stack extended focus imaging. Selected specimens were cast in epoxy resin (Ciba-Geigy: Araldite BY158 + Aradur 21) in a Struers CitoVac chamber, and the (non-silicified) skeletal carbonate was dissolved in hydrochloric acid upon sectioning with a rock saw. Selected casts were sputter coated with gold and visualised via scanning electron microscopy (SEM) with a Tescan VEGA 3 and a backscatter detector (BSE) at Senckenberg am Meer in Wilhelmshaven, Germany.

Micro-CT scans were performed with the ProCon CTALPHA of the Petrology of the Ocean Crust research group at the University of Bremen, Germany. The micro-CT was equipped with the X-RAY WorX source XWT-190-TCHE $(190 \mathrm{kV})$ with a high-energy target (W on diamond window) and the Hamamatsu C7942SK-25 CMOS flat panel detector with $2304 \times 2304$ pixels. For better spatial resolution (voxel size: 8.5 to $12.7 \mu \mathrm{m}$ ), the belemnite guards were measured in three partial scans each (except for the shortest fragment that contains the paratype of Lapispecus hastatus isp. n.). Raw data were reconstructed with Fraunhofer software VOLEX ver. 6.0, using a GPU-hosted modified Feldkamp algorithm based on filtered backprojection (Feldkamp et al., 1984). For noise reduction of the reconstructed data sets an Avizo bilateral filter (3-D mode, Morris belemnite) and a non-local mean filter (2-D mode, other scans), both within a local neighbourhood of 5 voxels (diameter of neighbourhood area), were applied.

All CT data post-processing was performed with the Amira ZIB edition of the Amira software version 2016.33 (Stalling et al., 2005; http://amira.zib.de). The partial scans were merged after manual adjustment of attenuation histograms (to compensate for filament degradation) and all further processing was performed on the entire specimens at the same voxel size of $12.7 \mu \mathrm{m}$. This spatial resolution allowed a reliable detection and segmentation of bioerosion traces down to about $50 \mu \mathrm{m}$ in dimension. The belemnites were segmented by threshold segmentation using the Multi-Thresholding module. Bioerosion trace segmentation was challenging because of the following facts: (i) the traces were filled by fine chalk sediments, which reduced the attenuation difference between the belemnite skeleton and the trace; (ii) there were slightly variable attenuation variations within the sediment filling the borings; (iii) there was partial replacement of the calcitic belemnite skeleton by silicification (complicating segmentation of Entobia colaria only) or pyrite (not negatively affecting final segmentation results); and (iv) because of the diminutive nature of some of the studied microbioerosion traces, causing artefacts in case of traces with minimum diameters smaller about 5 times the 
Table 1. Morphometric data for the various ichnotaxa recorded in the "Morris belemnite", in order of decreasing total volume; axes 1 to 3 describe the axes of the bounding box of the segmented trace.

\begin{tabular}{|c|c|c|c|c|c|c|c|}
\hline Ichnotaxon & $n$ & Axis $1 \quad(\mu \mathrm{m})$ & $\operatorname{Min} / \max (\mu \mathrm{m})$ & Axis $2(\mu \mathrm{m})$ & $\operatorname{Min} / \max (\mu \mathrm{m})$ & Axis $3(\mu \mathrm{m})$ & $\operatorname{Min} / \max (\mu \mathrm{m})$ \\
\hline Entobia isp. & 1 & 14976 & & 13203 & & 9106 & \\
\hline Talpina ramosa & $8^{\mathrm{a}}$ & $8074 \pm 14011$ & $962-42442$ & $3338 \pm 4830$ & $359-14359$ & $1611 \pm 3019$ & $220-9018$ \\
\hline Ramosulcichnus biforans & 5 & $11112 \pm 6533$ & $5269-21383$ & $3263 \pm 3052$ & $912-8406$ & $1711 \pm 1855$ & $543-4943$ \\
\hline Dendrina dendrina & 10 & $3659 \pm 1337$ & $2313-6597$ & $3162 \pm 1004$ & $1736-4842$ & $661 \pm 353$ & $388-1428$ \\
\hline Trypanites solitarius & 2 & $4897 \pm 655$ & $4434-5360$ & $714 \pm 88$ & $652-777$ & $355 \pm 22$ & $339-371$ \\
\hline Calcideletrix flexиоsa & 8 & $1375 \pm 731$ & 709-2401 & $957 \pm 478$ & $430-1894$ & $322 \pm 99$ & $164-434$ \\
\hline Dendrina lacerata & 6 & $1291 \pm 1068$ & $548-3403$ & $731 \pm 414$ & $336-1428$ & $254 \pm 93$ & $139-411$ \\
\hline Iramena isp. & $37^{\mathrm{b}}$ & $415 \pm 68$ & $207-507$ & $145 \pm 17$ & $103-180$ & $123 \pm 11$ & $92-151$ \\
\hline Trypanites isp. & 21 & $755 \pm 390$ & $317-1621$ & $223 \pm 160$ & $109-859$ & $135 \pm 51$ & $87-321$ \\
\hline
\end{tabular}

a 8 clusters of individual but connected segments.

b 37 zooidal chambers belonging to a single colony.

voxel diameter, particularly in the Morris belemnite. Consequently, the complexity of the sample material did not allow a uniform approach with respect to the applied segmentation algorithms and respective threshold values, and a combination of algorithm-based segmentation and some manual post-processing was necessary to achieve a satisfactory segmentation result. Pre-segmentation of the microborings in the Morris belemnite and the paratype of L. hastatus isp. $n$. was achieved by seed-based watershed segmentation, whereas contour-tree segmentation and threshold segmentation were used for the holotypes of L. hastatus isp. n. and Entobia colaria isp. n. All pre-segmentations required some degree of manual post-processing. Trace separation within the Morris belemnite was achieved with the ConnectedComponent module combined with manual post-processing. Cavity separation of E. colaria isp. n. was obtained with contourtree segmentation (persistence mode: adaptive; persistence value: 0.05 ) applied on a distance map of the boring. Again, manual post-processing was necessary for good segmentation results. The bioeroded volume and the lengths of the three axes of the bounding box of each segment were calculated with the ShapeAnalysis module. These are labelled as axis 1 to 3 (Table 1), with axis 1 being the longest and axis 3 the shortest. These figures were used to determine the anisotropy (i.e. 1 minus the ratio of the shortest to the longest axis, which measures the deviation from a spherical shape that would have a value of 0 ) and the elongation (i.e. the ratio of the medium to the longest axis; elongated objects have values close to 0 ) of some of the objects analysed. The axes furthermore served as a close approximation of the dimensions of the traces studied, or of individual segments of a trace. To determine the actual length of the winding course of Lapispecus types, a centreline was computed with the Centerline Tree module. After smoothing the obtained centreline with the Smooth Line Set module, its length was determined with the SpindleAnalysis module.

The processed 3-D models of the belemnite guards and the various bioerosion trace fossils are accessible via the online database PANGAEA in objects format (extension: obj) at https://doi.org/10.1594/PANGAEA.875121. These files can be displayed and further analysed with a number of commercial as well as open-source freeware 3-D tools such as MeshLab (http://www.meshlab.net). In addition to the object files, the 3-D models are provided in 3-D PDF format for interactive viewing (https://doi.org/10.1594/PANGAEA.875121).

This published work and the nomenclatural acts it contains have been registered in ZooBank on 8 May 2017 and received the LSID number D59520CA-4E44-40D0-AE1F057557C6F729: http://zoobank.org/references/D59520CA4E44-40D0-AE1F-057557C6F729.

\section{Results and discussion}

\subsection{The "Morris belemnite"}

The first case study concerns a belemnite depicted in a short paper by Morris (1851), who was one of the first to describe and illustrate the conspicuous bioerosion trace fossils in Late Cretaceous belemnite guards (see Fig. 1a for a partial reproduction of his plate IV). His investigations included the description of Talpina dendrina, which today is regarded the type ichnospecies of Dendrina, an ichnogenus described only two years earlier by Quenstedt (1849) but without designation of a type ichnospecies. This description and the respective type material received attention within the framework of a revision of the ichnofamily Dendrinidae Bromley et al., 2007, recently undertaken by the senior author of the present paper (Wisshak, 2017). The specimen, herein referred to as the "Morris belemnite" was borrowed from the Natural History Museum, London, where it is registered as NHMUK PI A 559, in order to investigate $D$. dendrina further and designate a lectotype. This step was deemed necessary because Morris himself did not designate a type (Wisshak, 2017). The Morris belemnite (Fig. 1b) stems from the Upper Cretaceous chalk near Norwich (England). The type stratum was not specified in more detail by Morris, 

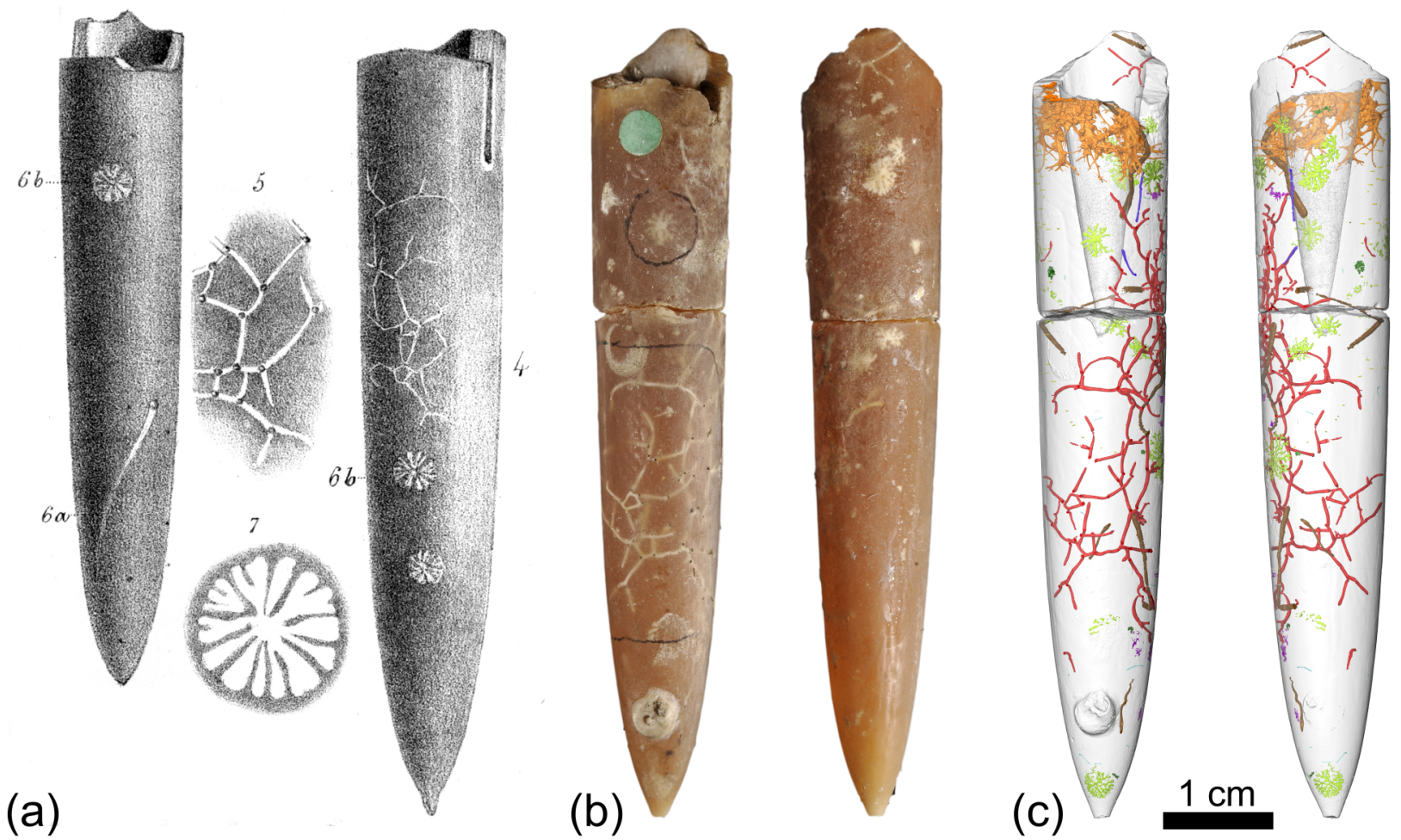

Figure 1. The "Morris belemnite" from the upper Campanian to lower Maastrichtian (Upper Cretaceous) chalk of Norwich, Norfolk, England. (a) Original illustrations reproduced from Morris (1851: pl. IV, figs. 4-7; labels 4 and 5: Talpina ramosa; 6a: Trypanites solitarius; $6 \mathrm{~b}$ and 7: Dendrina dendrina). (b) The original belemnite, reposited at the Natural History Museum London (PI A 559); the lectotype of Dendrina dendrina is encircled next to the green sticker. (c) Micro-CT scan of the belemnite with segmented bioerosion trace fossils separated in colour by ichnospecies.

but the Upper Cretaceous in Norfolk comprises the Turonian to lower Maastrichtian and the belemnite's taxonomic identity (Belemnitella; identification backed up by the exact shape and position of the alveolar fissure detected in the present micro-CT data set) narrows down the stratigraphical range to upper Campanian to lower Maastrichtian. The Morris belemnite contains 10 specimens of $D$. dendrina, one of which - the one encircled with ink on the original belemnite (Figs. 2b-c and 3b-d) - was designated as lectotype by Wisshak (2017), rendering the other specimens on the same belemnite paralectotypes.

The reinvestigation of the Morris belemnite, however, was limited to classic transmission and reflected light microscopy, owing to the fact that a type, once fixed, should not be altered (as implied by article 72.10 and recommendation $72 \mathrm{~F}$ of the International Code of Zoological Nomenclature; ICZN, 1999). This prohibited the application of the widely used, albeit destructive, cast-embedding technique and subsequent SEM visualisation, and called for non-destructive computer tomography instead (Fig. 1c). In the following account, the outcome of both these methods is presented and compared.
The Morris belemnite is broken in two parts, together $72 \mathrm{~mm}$ in length, and harbours a diverse bioerosion trace fossil assemblage. It is already apparent from first view that there is good resemblance in detail between Morris' figs. 4 to 6 and the actual original belemnite specimen, but that there was some degree of "artistic freedom" concerning the position of the depicted traces on two, instead of a single, belemnite guards (compare Figs. 1a and b). While Morris limited himself to illustrating three different types of bioerosion trace fossils only, namely Dendrina dendrina, Talpina ramosa, and Trypanites solitarius, the present analysis shows that the belemnite actually bears traces of at least 10 different ichnospecies (Figs. 2-6). Owing to the partial transparency of the calcitic skeletons in many Late Cretaceous belemnites, the majority of the bioerosion traces could tentatively be identified with the naked eye or a microscope (Fig. 2), namely Dendrina dendrina (Fig. 2b-f), Entobia isp. (Fig. 2g), Calcideletrix flexuosa (Fig. 2h-i), Talpina ramosa (Fig. 2j), Orthogonum lineare (Fig. 2k), Iramena isp. (Fig. 2l), and some unidentifiable fungal microborings (Fig. $2 \mathrm{~m}$ ). The subsequent micro-CT analysis allowed segmentation and separation of the individual bioerosion trace 

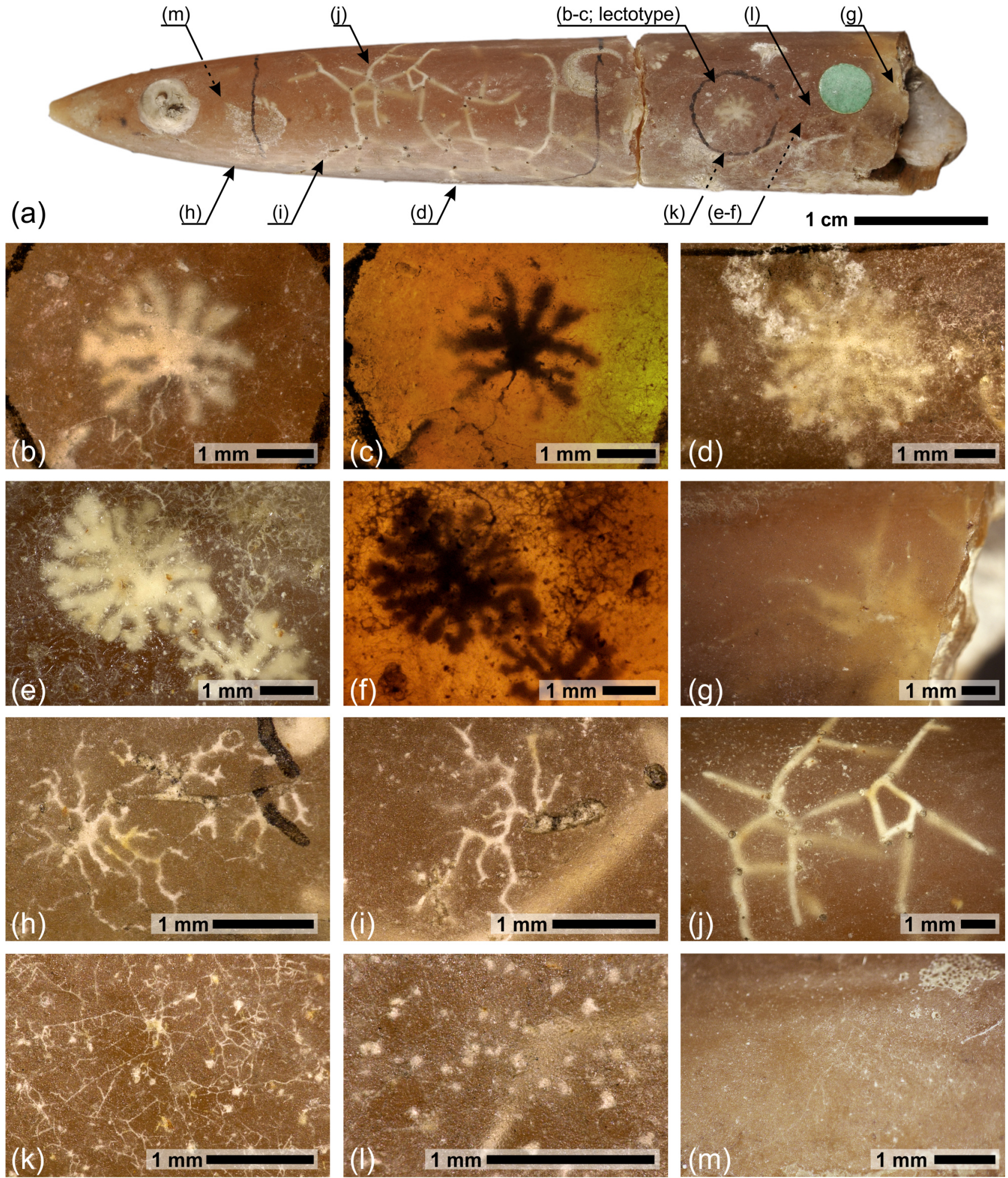

Figure 2. Bioerosion trace fossils in the "Morris belemnite". (a) Overview with the locations of the traces illustrated in panels (b)-(m). (b, c) Lectotype of Dendrina dendrina (Morris, 1851) photographed in reflective and transmission light. (d-f) Three further specimens of $D$. dendrina. (g) Vaguely visible sponge boring Entobia isp. (h, i) Two specimens of Calcideletrix flexuosa Mägdefrau, 1937. (j) Central part of a large phoronid boring, Talpina ramosa von Hagenow, 1840. (k) Superficial network of hyphal filaments of the fungal microbioerosion Orthogonum lineare Glaub, 1994. (l) Orifices of individual zooid chambers of the bryozoan trace Iramena isp. (m) Undefined minute fungal microbioerosion trace. 
fossils and a more detailed morphological and morphometric analysis (Figs. 3-6; Tables 1-2):

Two ichnospecies of the dendrinid ichnogenus Dendrina were identified. These are 10 complete specimens of the type ichnospecies D. dendrina (Morris, 1851) (Fig. 3b-j), and six specimens of D. lacerata Hofmann, 1996 (Fig. 3k-m). The rosettes of $D$. dendrina were found running closely parallel and in consistent distance to the substrate surface. The documented rosettes comprise various ontogenetic stages, 2.3 to $6.6 \mathrm{~mm}$ in maximum diameter at a mean of $3.7 \pm 1.4 \mathrm{~mm}$ (see Tables 1 and 2 for more detailed morphometric data). They illustrate the morphological range nicely, from traces with a somewhat fused central cavity and relatively wide lobes (e.g. Fig. 3b-d) to traces with only a small central area from which narrower and more strongly meandering lobes radiate (e.g. Fig. 3e-g). The initial entry canal, visible in light micrographs, was partly beyond the detection limit of the given spatial resolution of the scan (compare Figs. $2 b-c$ and $3 b-c$ ), as were the finer ones of the apertural canals connecting the rosette to the substrate surface that are otherwise visible in epoxy resin casts (Wisshak, 2017). A total of six specimens of the smaller D. lacerata were found, ranging from 0.5 to $3.4 \mathrm{~mm}$ in maximum diameter at a mean of $1.3 \pm 1.1 \mathrm{~mm}$. Similar to $D$. dendrina, the irregularly lobed main cavity is oriented parallel to the substrate surface, but it is connected to the latter by a single perpendicular entrance tunnel only (Fig. $3 \mathrm{~m}$ ). The trace makers of these dendrinids are unknown but could possibly have been either bioeroding microsponges or naked foraminiferans (for a review of hypotheses, see Wisshak, 2017).

The most voluminous individual bioerosion trace in the Morris belemnite is the sponge boring Entobia isp. (Fig. 4ad). This shows some resemblance to E. mammillata Bromley and D'Alessandro, 1984 and E. retiformis (Stephenson, 1952) with respect to the long, slender, and branching exploratory threads as well as the fused chambers that form a larger, irregular excavation, in some parts with hemispherical tubercles. However, the trace is too small and fragmentary to allow proper identification at the ichnospecies level. The trace-making sponge appears to have settled on the inside of the alveolus, where the trace seems to originate. The location of settlement is indicated by the density of bioerosion in this area and the orientation of the exploratory threads (Fig. 4d). Their partial separation from the main excavation would suggest either the presence of some epilithic sponge tissue or concurrent bioerosion of the unpreserved phragmocone inside the alveolus.

A trace that sits at the limit of detection with the chosen spatial resolution of the present micro-CT scan is Calcideletrix flexuosa Mägdefrau, 1937 (Fig. 4e-h). Although the relatively juvenile traces of this dendrinid ichnospecies can be identified clearly via light microscopy (Fig. $2 \mathrm{~h}-\mathrm{i}$ ), its fine galleries were mostly too diminutive to be shown properly in the micro-CT scan. The trace maker of $C$. flex- uosa is unknown, but it was possibly either a bioeroding microsponge or a naked foraminiferan (Wisshak, 2017).

The largest and most conspicuous bioerosion trace in the Morris belemnite is Talpina ramosa von Hagenow, 1840 (Fig. 5a-d). Traces of this ichnospecies presumably are the work of pseudo-colonial phoronid worms (e.g. Voigt, 1972, 1975). The largest of the present specimens, $42 \mathrm{~mm}$ in maximum extension, comprises a network of fused individual phoronid borings, each with a circular aperture at the substrate surface and a single tunnel of relatively consistently oval to circular cross section, arching from the vertical entrance back towards the surface. In the centre of the trace, several polygonal rings of merged tunnels are developed (Fig. 5b-c). The morphology of this specimen of T. ramosa is in good accordance with the lectotype recently designated by Wisshak et al. (2017b).

With respect to cylindrical bioerosion traces, several forms can be distinguished, the first of which actually is part of a network boring. These are the vertically oriented zooidal chambers of a boring bryozoan with affinity to the genus Penetrantia, which are ichnotaxonomically addressed by the ichnogenus Iramena (Fig. 5e-h) as established by Boekschoten (1970). The vertical and blindly terminating tunnels (individually segmented and counted for Tables 1 and 2) are only 0.2 to $0.5 \mathrm{~mm}$ in length with a mean of $0.4 \pm 0.1 \mathrm{~mm}$ and ca. 0.1 to $0.2 \mathrm{~mm}$ in diameter. Tubular tunnels connecting the individual zooidal penetrations, the so-called stolons, are not preserved or were below the limit of resolution in the present micro-CT scan. Hence, the ichnospecies cannot be identified; it is either I. danica Boekschoten, 1970 or I. bonaresi Mayoral, 1988. In general, bioerosion traces of ctenostome bryozoans are in urgent need of revision.

True solitary cylindrical bioerosion traces are principally represented by the large Ramosulcichnus biforans (Gripp, 1967) (Fig. 6a-d). Its tunnel measures up to $21 \mathrm{~mm}$ in length with a mean of $11 \pm 7 \mathrm{~mm}$. After a short stretch, its flattened entrance tunnel follows a zig-zag course, before continuing roughly parallel to the substrate surface and terminating in a widened tongue-shaped manner. The rare presence of ramifications such as proposed by Hillmer and Schulz (1973) was not recorded in the present scan. This trace was interpreted as the work of spionid polychaetes (Hillmer and Schulz, 1973). In addition to Ramosulcichnus, two forms of Trypanites were recorded in the Morris belemnite (Fig. 6e-k). The larger one of these is the classic T. solitarius (von Hagenow, 1840), which is characterised by a blindly ending tunnel of roughly constant diameter and up to $5.4 \mathrm{~mm}$ in length at a mean of $4.9 \pm 0.7 \mathrm{~mm}$ (Fig. $6 \mathrm{f}-\mathrm{h}$ ). From the circular aperture these tunnels curve towards a more substrate-parallel course and may be interrupted by a flattened S curve, similar in fashion to that in $R$. biforans but a single zig-zag only. Both overall shape and dimension are very similar to the individual segments of $T$. ramosa, lending credit to the view that these borings might have been produced by phoronid worms as 


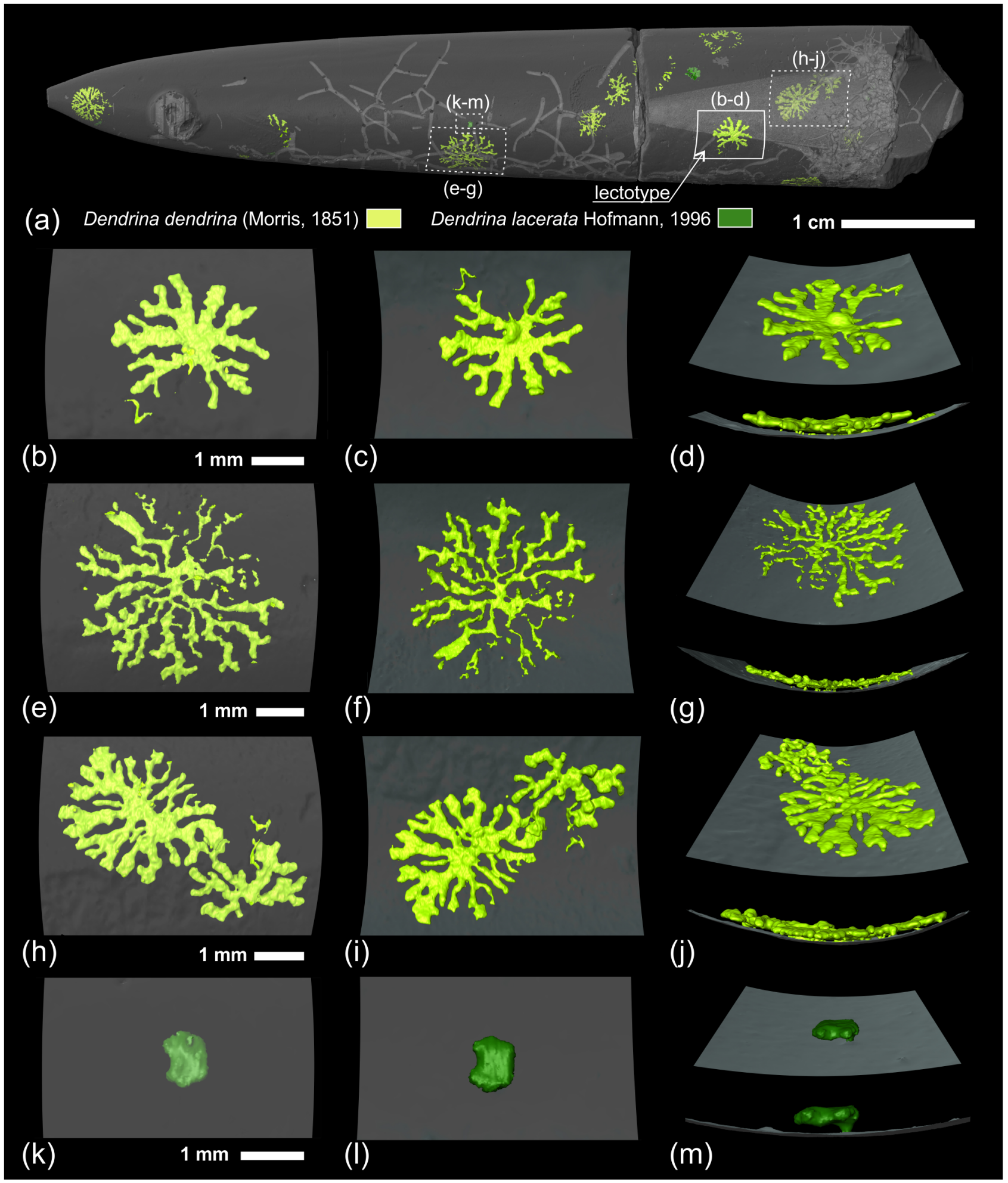

Figure 3. Micro-CT scan of the "Morris belemnite" illustrating the bioerosion traces Dendrina dendrina (Morris, 1851) and Dendrina lacerata Hofmann, 1996. (a) Overview with the locations of the traces illustrated in panels (b)-(m). (b-j) Plan, oblique, and lateral views of four specimens of $D$. dendrina; the lectotype is depicted in (b)-(d). (k-m) Plan, oblique, and lateral view of a specimen of $D$. lacerata. 


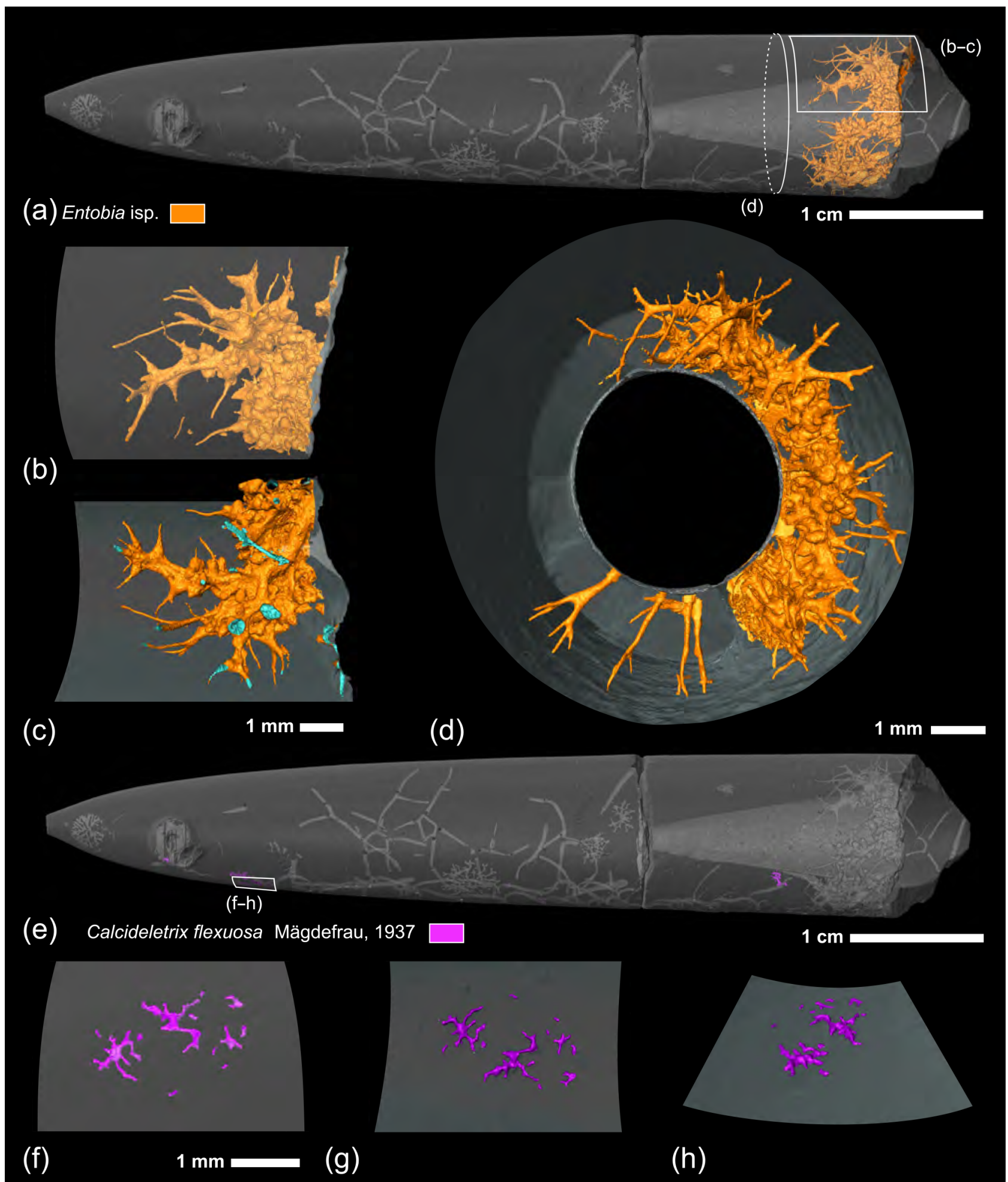

Figure 4. Micro-CT scan of the "Morris belemnite" illustrating the bioerosion traces Entobia isp. and Calcideletrix flexuosa Mägdefrau, 1937. (a) Overview with the locations of the trace illustrated in panels (b)-(d). (b, c) Two opposite views of part of the Entobia trace. (d) Cross section of the belemnite guard showing the radial orientation of Entobia, originating from inside the alveolus. (e) Overview with the locations of the trace illustrated in panels (f)-(h). (f-h) Plan and oblique views of a specimen of $C$. flexuosa, only poorly resolved at the given spatial resolution of the scan. 


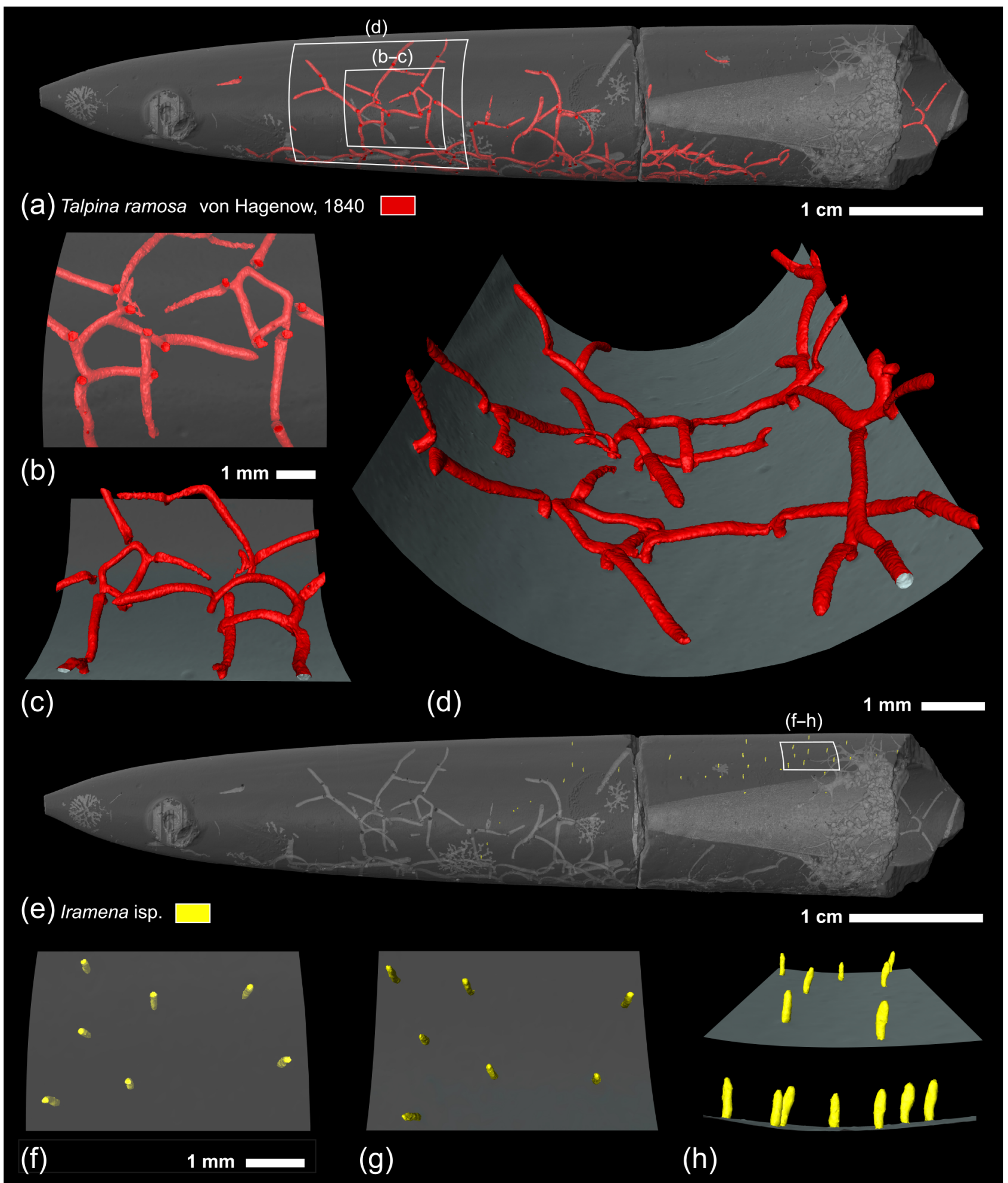

Figure 5. Micro-CT scan of the "Morris belemnite" illustrating the bioerosion traces Talpina ramosa von Hagenow, 1840 and Iramena isp. (a) Overview with the locations of the close-ups in panels (b)-(d). (b-d) Plan and oblique views of the centre of a the trace T. ramosa, showing the arched nature of the fused individual borings, each connected to the surface by a circular opening. (e) Overview with the locations of the close-up in panels (f)-(h). (f-h) Plan and oblique views of a cluster of zooidal chambers of Iramena isp.; the stolons interconnecting these vertical penetrations are not resolved. 
Table 2. Volumetric data for the various ichnotaxa recorded in the "Morris belemnite", in order of decreasing total volume.

\begin{tabular}{|c|c|c|c|c|c|c|}
\hline Ichnotaxon & $n$ & $\begin{array}{r}\text { Volume } \\
\text { total }\left(\mathrm{mm}^{3}\right)\end{array}$ & $\begin{array}{r}\% \text { of } \\
\text { belemnite }\end{array}$ & $\begin{array}{r}\% \text { of } \\
\text { bioerosion }\end{array}$ & Volume individual $\left(\mathrm{mm}^{3}\right)$ & $\operatorname{Min} / \max \left(\mathrm{mm}^{3}\right)$ \\
\hline Entobia isp. & 1 & 36.8385 & 0.6230 & 58.7475 & 36.8385 & - \\
\hline Talpina ramosa & $8^{\mathrm{a}}$ & 14.0705 & 0.2379 & 22.4387 & $1.7588 \pm 4.4990$ & $0.0178-12.8814$ \\
\hline Ramosulcichnus biforans & 5 & 7.6536 & 0.1294 & 12.2055 & $1.2712 \pm 1.1789$ & $0.1485-2.9861$ \\
\hline Dendrina dendrina & 10 & 3.2318 & 0.0547 & 5.1539 & $0.3130 \pm 0.1682$ & $0.1273-0.5939$ \\
\hline Trypanites solitarius & 2 & 0.2915 & 0.0049 & 0.4649 & $0.1458 \pm 0.0045$ & $0.1425-0.1490$ \\
\hline Calcideletrix flexuosa & 8 & 0.2736 & 0.0046 & 0.4363 & $0.0342 \pm 0.0319$ & $0.0124-0.0912$ \\
\hline Dendrina lacerata & 6 & 0.1496 & 0.0025 & 0.2385 & $0.0249 \pm 0.0247$ & $0.0100-0.0748$ \\
\hline Iramena isp. & $37^{\mathrm{b}}$ & 0.1149 & 0.0019 & 0.1832 & $0.0031 \pm 0.0009$ & $0.0010-0.0044$ \\
\hline Trypanites isp. & 21 & 0.0825 & 0.0014 & 0.1316 & $0.0039 \pm 0.0035$ & $0.0008-0.0143$ \\
\hline Belemnite & & 5913.3819 & & & & \\
\hline Bioerosion & & 62.7065 & 1.0604 & & & \\
\hline
\end{tabular}

a 8 clusters of individual but connected segments.

b 37 zooidal chambers belonging to a single colony.

well, providing an alternative to the common interpretation of sipunculid worms as producers of Trypanites (e.g. Bromley, 1972; Neumann et al., 2008). The morphology of the present $T$. solitarius agrees well with the lectotype recently designated by Wisshak et al. (2017b). There is, however, a second type of Trypanites preserved in the Morris belemnite (Fig. 6i-k). It is smaller in dimension but of a similar proportion, with a maximum length of $1.6 \mathrm{~mm}$ at a mean of $0.8 \pm 0.4 \mathrm{~mm}$. In contrast to typical T. solitarius, this morphotype is oriented more perpendicularly with respect to the substrate surface, such as in T. weisei Mägdefrau, 1932, and the termination appears slightly widened, resulting in affinity also with the ichnogenus Palaeosabella.

A volumetric analysis of individual traces (Table 2) reveals that only a total of $1.1 \%$ by volume of the belemnite is bioeroded, in spite of the high ichnodiversity and large number of individual bioerosion traces. In the Morris belemnite, it is an Entobia that accounts for the largest bioeroded volume, with an individual volume of $37 \mathrm{~mm}^{3}$, equating to $0.6 \%$ of the total and $59 \%$ of the bioeroded volume, respectively. All traces of other ichnospecies have an individual mean volume of less than $2 \mathrm{~mm}^{3}$, and only $T$. ramosa and $R$. biforans account for more than $10 \%$ of the bioeroded volume (see Table 2 for detailed morphometric figures).

\subsection{The new bioerosion trace fossil Lapispecus hastatus}

The second case study concerns two belemnites of the species Gonioteuthis quadrata (de Blainville, 1827) from the lower Campanian limestones of Höver, Germany, that were scanned with micro-CT in order to visualise and analyse type material of a new bioerosion trace fossil assigned to the ichnogenus Lapispecus Voigt, 1970 (Figs. 7-9). In the literature, references to Lapispecus, other than the detailed original description by Voigt (1970) and some additional observations published by the same author a year later (Voigt, 1971), are scarce (e.g. Bromley, 1972, 2004; Häntzschel, 1975; Martinell and Domènech, 1981; Bromley and D'Alessandro, 1987; Radtke, 1991; Jagt, 2003; de Almeida, 2007). Bromley (1972) found that Lapispecus also occurred in Upper Cretaceous belemnite rostra from the Campanian of Norwich, England, and regarded Lapispecus as a valid ichnogenus distinct from Trypanites. Bromley and D'Alessandro (1987) only tentatively assigned some borings in a Plio-Pleistocene rocky shore to Lapispecus, a record that would indicate that the trace maker of Lapispecus had survived the end-Cretaceous mass extinction event, allowing the ichnogenus to range throughout most of the Cenozoic. However, their illustrations do not allow unequivocal identification as Lapispecus. The same applies to the early Holocene record noted by Martinell and Domènech (1981), which was not illustrated and whose verification is pending. However, definite records do stem from the Palaeocene to Eocene upper Maia Farinha Formation in Bacia da Paraíba, Brazil (de Almeida, 2007), and from the Eocene Marno de Passagno, Italy (Radtke, 1991). These confirm the stratigraphical range of Lapispecus at least into the early Cenozoic.

Coming back to the new material from the Late Cretaceous belemnite rostra from the European chalk basin (Fig. 7), the only indication of the trace visible from the outside is the presence of conspicuous dotted to dashed lines of minute openings that spiral the belemnite and occasionally seem to branch (Fig. 7). When the slightly transparent belemnites are observed under transmission light, a tunnel below these lines on the surface can be picked out (Fig. 7c), but the true three-dimensional morphology remains hidden in the rostra. Epoxy casting is compromised or prone to failure because these borings are filled with chalk sediment and the rostra have undergone a significant degree of silicification (Fig. 7h). Thus, the most practical methodological approach is micro-CT. By applying this method, the bioerosion 


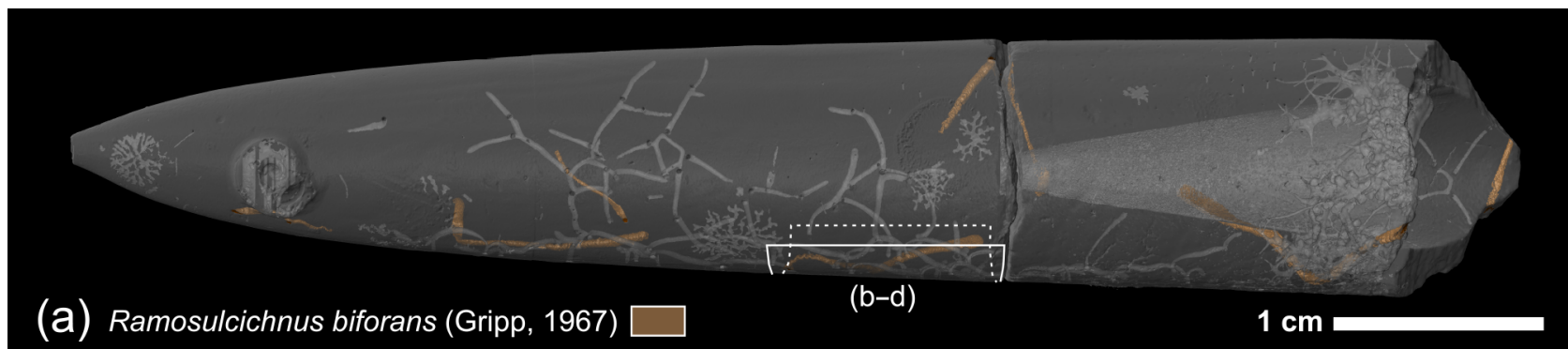

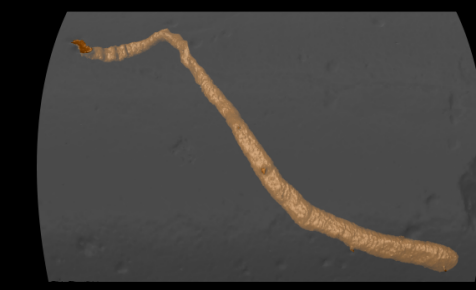

(b)

$1 \mathrm{~mm}$

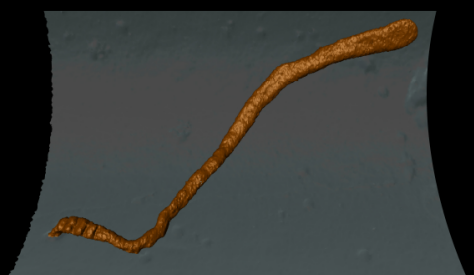

(c)

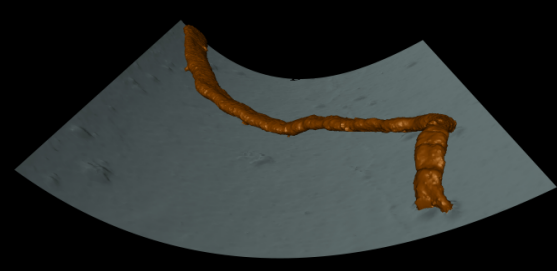

(d)

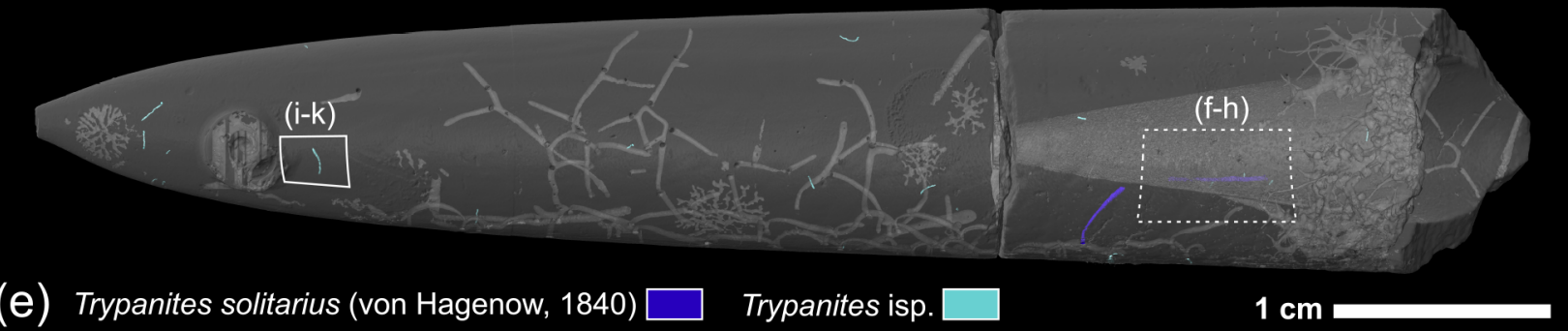

(e) Trypanites solitarius (von Hagenow, 1840)

Trypanites isp.

$1 \mathrm{~cm}$

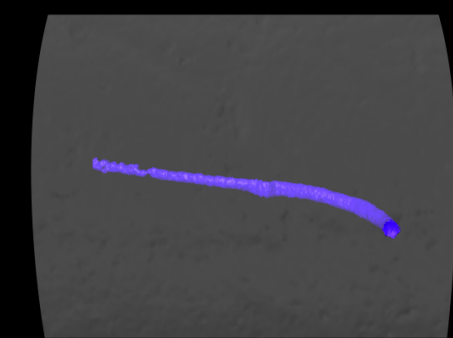

(f)

$1 \mathrm{~mm}$

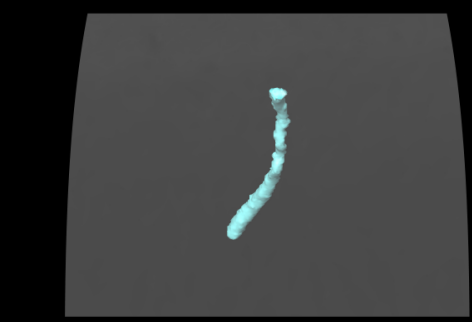

(i)

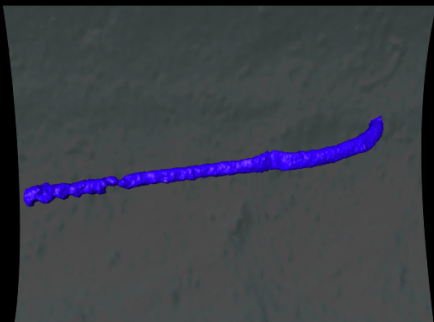

(g)

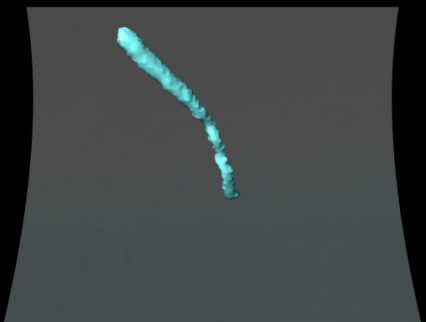

(j)

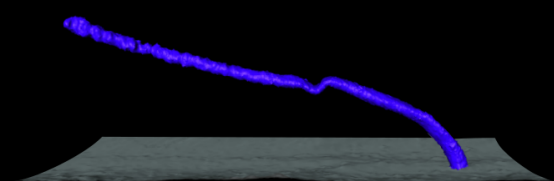

(h)

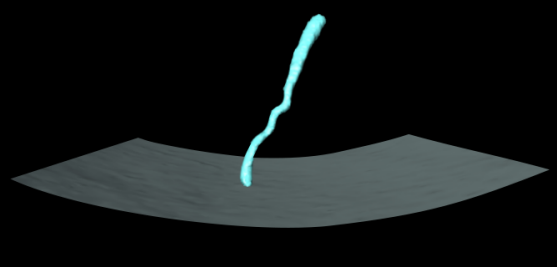

$(\mathrm{k})$

Figure 6. Micro-CT scan of the "Morris belemnite" illustrating the bioerosion traces Ramosulcichnus biforans (Gripp, 1967), Trypanites solitarius (von Hagenow, 1840) and Trypanites isp. (a) Overview with the locations of the close-ups in panels (b)-(d). (b-d) Plan and oblique views of a specimen of $R$. biforans displaying the flattened zig-zag constriction near the entrance of the cylindrical tunnel. (e) Overview with the locations of the traces illustrated in panels (f)-(k). (f-h) Plan and lateral views of a specimen of T. solitarius. (i-k) Plan and lateral views of the smaller, more vertically penetrating Trypanites isp. 

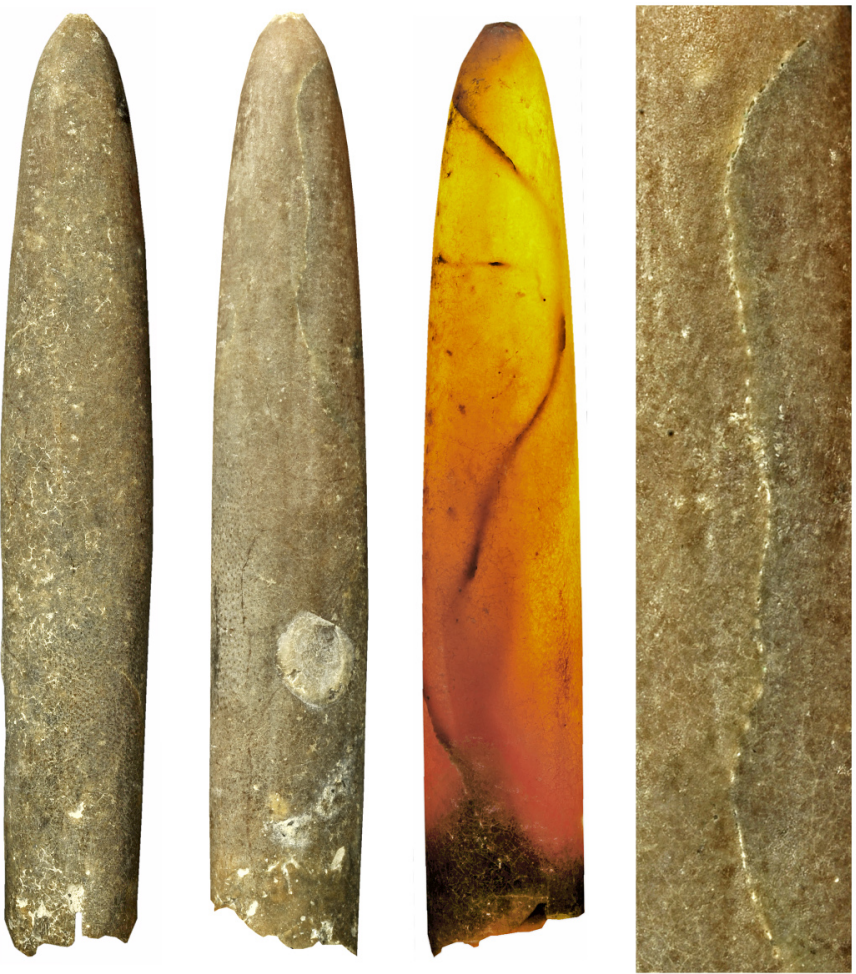

(a) $1 \mathrm{~cm}$

(b) (c)

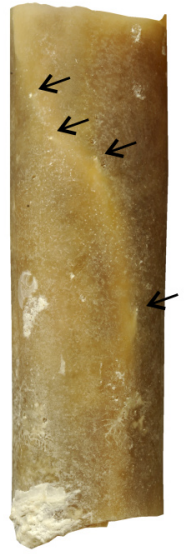

(i)

(i) $5 \mathrm{~mm}$

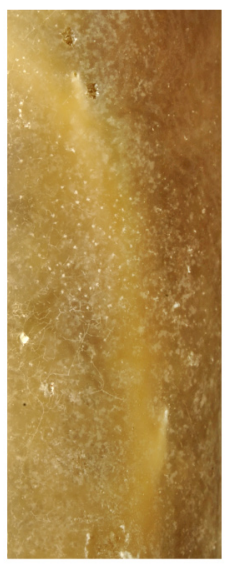

(j) $1 \mathrm{~mm}$ (d) $1 \mathrm{~mm}$

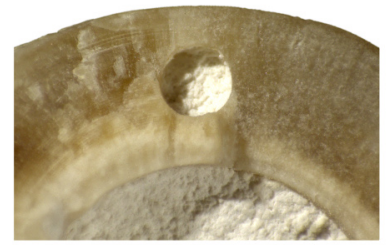

(k)

$1 \mathrm{~mm}$

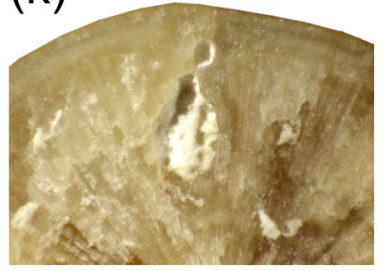

(I)
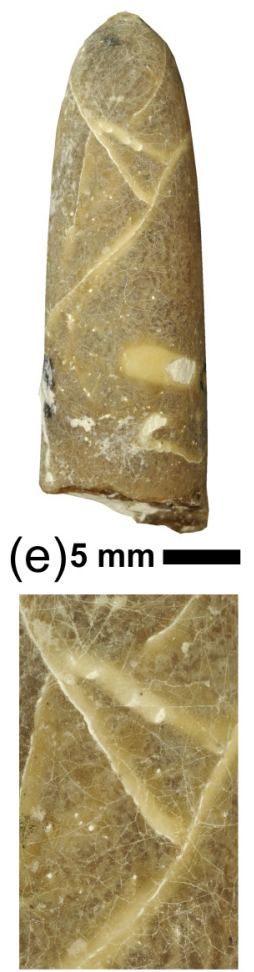

(f) $1 \mathrm{~mm}=(\mathrm{g})$

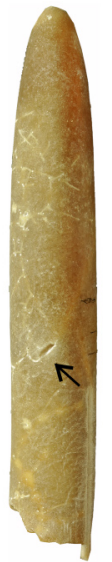

(m)

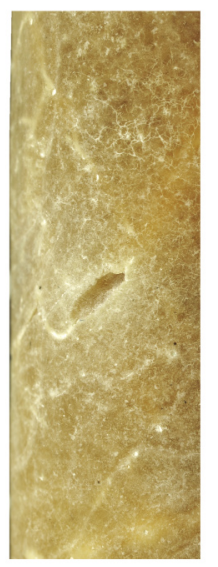

(n) $1 \mathrm{~mm}=$
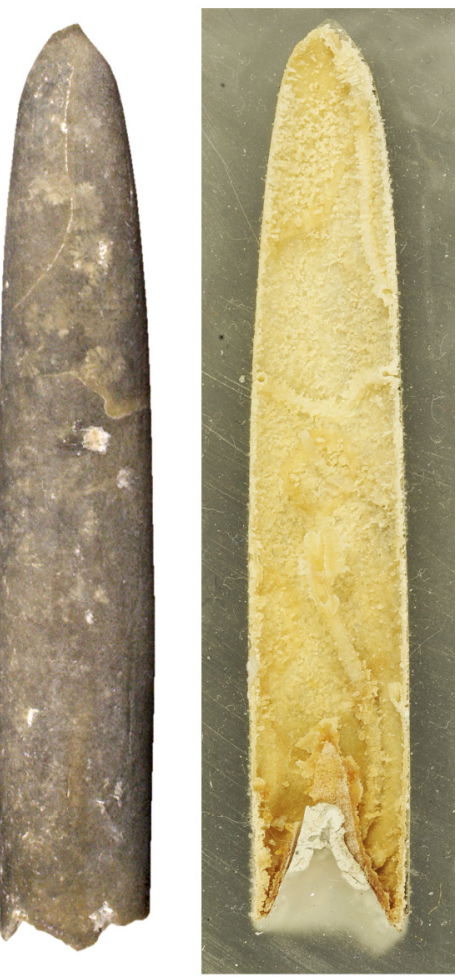

(h)

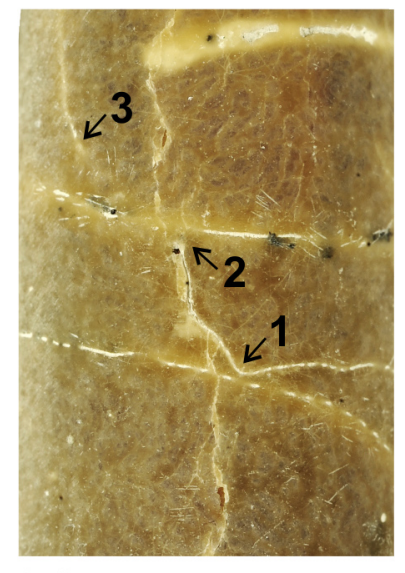

(o)

$1 \mathrm{~mm}$

Figure 7. Lapispecus hastatus isp. n. in belemnite rostra from the Upper Cretaceous of northern Germany. (a-c) Ventral, dorsal and transmission light views of a specimen of Gonioteuthis quadrata from the lower Campanian of Höver that bears the holotype. (d) Close-up of the holotype, illustrating the characteristic dotted to dashed outline of the vane on the surface. (e-f) Overview and close-up of the guard of G. quadrata from the lower Campanian of Höver that bears the paratype, illustrating both the false and true branching patterns as appearing on the surface of the belemnite (see Fig. 9 for explanation). (g-h) Another specimen from the lower Campanian of Höver prior to and after epoxy casting, demonstrating the typical degree of silicification, particularly near the surface, compromising good casting results. (i-j) Overview and close-up of a specimen of Belemnella lanceolata from the lower Maastrichtian of Rügen, bearing the proximal gallery of a specimen of Lapispecus with wide spacing of only a few pointed connections to the substrate surface (arrows). (k-l) Proximal and distal end of the same fragment, showing the circular section of the entrance tunnel and a more oval cross section with partial vane a bit further along the trace. ( $\mathbf{m}-\mathbf{n})$ Overview and close-up of a belemnite from the upper Campanian of Kronsmoor with the rare instance of a specimen of Lapispecus entering the guard from the side. (o) Close-up of a guard of G. quadrata from the lower Campanian of Höver, showing the vane of Lapispecus spiralling around the guard, hitting its own tunnel under an acute angle and making a sharp right turn (1), hitting its own tunnel perpendicularly (2), delving below and reappearing on the other side (3). 
traces in the two belemnites in question were successfully visualised, allowing for a detailed morphological description and morphometric measurements (Fig. 8). One of the belemnites is devoid of any other borings and contains only an idiomorphic specimen of Lapispecus (Fig. 8a-g), while the other demonstrates crowded bioerosion traces, including, for example, Entobia isp., Ramosulcichnus biforans, and many microborings. It contains one specimen of Lapispecus with a complex branching pattern (Figs. 8h-1, 9). Together, the data of the two scans revealed morphological features absent from or atypical of the type ichnospecies, L. cuniculus, warranting the description of a new ichnospecies. This is also a good opportunity to reassess the ichnotaxonomy of the ichnogenus Lapispecus, including translation and emendation of the original ichnogenus diagnosis, and to add a diagnosis of the type ichnospecies (formerly equivalent to ichnogenus diagnosis). Furthermore, the new micro-CT visualisations allow deeper insight into the behavioural patterns and the identity of its trace maker, probably a sipunculan or phoronid worm.

\section{Lapispecus Voigt, 1970}

Type ichnospecies: Lapispecus cuniculus Voigt, 1970 by original designation.

Diagnosis: Lange, an Dicke nur sehr langsam zunehmende zylindrische Tunnelgänge in Steinen (Karbonatgeröllen), je nach dem verfügbaren Raum entweder in engen Windungen knäuelartig zusammengerollt oder in weiten Bögen oder Schleifen das Gestein durchziehend. An den Enden der Schleifen zuweilen mit spreitenartigen Bildungen, die - im Steinkern - als Lappen oder schmale, scharf abgesetzte Säume die Röhrenausfüllungen streckenweise auf einer Seite begleiten. Phylum, Klasse und Ordo innerhalb der "Vermes" unbestimmt, wahrscheinlich den Polychaeten zuzuordnen. [Translation from German: Long, only gradually widening, cylindrical tunnels in rocks (calcareous cobbles), penetrating the rock either twine-like in narrow windings or in wider bends or ribbons, depending on available space. At the turns of the ribbon, occasionally spreiten-like structures are developed that - in the internal mould - run along part of the tunnel as a narrow and sharply distinct vane. Phylum, class, and order within the "Vermes" uncertain, probably attributable to polychaetes.]

Emended diagnosis: Long, cylindrical tunnels in lithic calcareous substrates, penetrating the substrate either twinelike in narrow windings or in wider ribbons, depending on available space. Occasionally a vane is developed between the concave side of the tunnels, whereas, more commonly, a narrow and distinct vane runs along most parts of the tunnel, connecting it to the substrate surface.
Remarks: The diagnosis was translated and emended in order to accommodate the two ichnospecies better, and to disconnect it from its biological interpretation. Without doubt Lapispecus describes the morphology of a bioerosion structure and thus clearly should be regarded as an ichnotaxon, despite the tentative link to a polychaete worm agent, as specified in the original diagnosis.

\section{Lapispecus cuniculus Voigt, 1970}

$\begin{array}{ccl}* & 1970 \quad \begin{array}{l}\text { Lapispecus cuniculus - Voigt: 362-375, } \\ \text { pls. 1-5 }\end{array} \\ ? \quad 1971 & \begin{array}{l}\text { Lapispecus cf. cuniculus - Voigt: 148-149, } \\ \text { fig. 1, pl. 15: figs 10-11 (fragments only) }\end{array} \\ ? \quad 1972 & \begin{array}{l}\text { Lapispecus cuniculus - Bromley: 97, pl. 18 } \\ \text { Lapispecus cuniculus - Häntzschel: W78, } \\ \text { fig. 48/5a-d (reproduced from Voigt 1970) }\end{array} \\ 1975 \quad 1991 & \begin{array}{l}\text { Lapispecus cuniculus - Radtke: 53-54, pl. } \\ \text { 3: fig. 3 (fragment only) } \\ \text { Lapispecus cuniculus - Almeida: 92-94, } \\ \text { fig. 26, pl. III: fig. 6 (fragment only) }\end{array} \\ \text { ? } 2007\end{array}$

Diagnosis: Main tunnel relatively constant in circular diameter, curled in partially tight windings close to the substrate surface or keeping close contact to earlier curls of its own tunnel. A thin vane may be developed between the tunnels on the concave side of windings and between the main tunnel and the substrate surface. Tunnels may cut through each other but more generally avoid breaking through into pre-existing tunnels or to the substrate surface.

Type material, locality, and stratum: The holotype is the natural cast illustrated by Voigt (1970, pl. 2, figs. 5-7), housed at the Institute for Geology at the University of Hamburg, Germany, under the inventory number 1299. It was found in a disused and partially filled quarry on the Scharenberg, at the western limit of Bündheim near Bad Harzburg, Germany, in reworked (probably Kimmeridgian, Upper Jurassic) limestone cobbles within a Santonian (Upper Cretaceous) transgressive conglomerate.

Remarks: Number and morphology of openings to the substrate surface unknown, since all known specimens originate from abraded coastal cobbles. Thus, Voigt (1970) only speculated about the likelihood of two entrances, in analogy to other polychaete borings such as Caulostrepsis. Voigt (1970) had reported L. cuniculus cutting through other tunnels (of Lapispecus and other ichnospecies). However, these represent false branching and should not be confused with the true branching observed for L. hastatus isp. n. (see below). The clear distinction of Lapispecus from Trypanites, as considered by Bromley (1972), is confirmed by the presence of true branches in the new ichnospecies. 
Lapispecus hastatus isp. $\mathbf{n}$.

Figs. 7-9

? 1973 Nygmites solitarius - Hillmer and Schulz: 15-17, fig. 7, pl. 3: fig. 2

2013 unbestimmter Bohrgang - Girod and Rösner: 282 , fig. 8 (now the paratype)

2017 Lapispecus isp. - Buatois et al.: 151, fig. $61 \mathrm{~B}$

Etymology: From hastatus (Latin, meaning "carrying a lance"), referring to the circular entrance and blade-shaped terminus of the trace, giving it the overall appearance of a (strongly bent) lance.

Diagnosis: Circular to oval single entrance leading to a cylindrical tunnel that runs closely parallel below the substrate surface and is connected to the latter by a thin, intermittent vane that appears on the surface as a dotted to dashed line of minute openings. The diameter of the main tunnel gradually decreases from proximal to distal, and the keyhole-shaped cross section (where the vane is present) becomes more slender, before ending in a lance-shaped termination. Where the tunnel hits itself or an obstacle, a blind termination is developed and a new branch emerges under an acute angle, circumnavigating the obstacle by delving deeper into the substrate for a short distance.

Description: Where belemnite rostra form the host substrate, with only a few exceptions, the single entrance of the trace is located near or in the alveolus and has a circular to oval outline, depending on the inclination of the initial penetration (Figs. 7a-c, g-h, 8a-b, g). From there, the proximal cylindrical tunnel, perfectly circular in cross section (e.g. Fig. 7k), runs towards the tip of the rostrum and is connected to the substrate surface along most of its length by a thin vane (Fig. 8a-g), resulting in a keyhole- to teardrop-shaped cross section (e.g. Figs. 7l, 8f). The vane does not appear along the entire length of the trace, but it is intermittent and in the most proximal part of the main tunnel it is absent (Fig. 8a-b, f-g) or exhibits only a few connections to the substrate surface, pointed in the direction of growth (Fig. 7i-j). In part, the vane undulates and does not always extend all the way to the substrate surface. Where it does, it is visible on the surface of the belemnite as a dotted to dashed array of minute openings (e.g. Figs. 7d, 8e). The tunnel gradually decreases in diameter (the keyhole cross section becomes more slender) and runs nearly parallel to the substrate surface. Near the tip of the belemnite, the tunnel makes a wide turn and is directed back to where it came from. Where the tunnel hits itself (or other traces) under an acute angle, the tunnel makes a turn and continues (Fig. 7o). Where the tunnel hits itself under a closer to right angle, the tunnel tapers and abruptly ends, rendering the impression of a false branching. Just prior to this termination, a true branch is developed that deviates under an acute angle from the original tunnel and delves deeper into the substrate, circumnavigating the obstacle, before turning back towards its common course closely parallel to the substrate surface (Figs. 7o, 8h-1, 9). Towards the distal termination of the tunnel, the cross section ultimately changes into a vertically flattened, lance-shaped termination (Fig. 8g). Traces with a confirmed second opening of the main tunnel to the substrate surface have not been observed (merely the vane connects to the surface), but abrasion of the substrate or collapse of the roof has been observed to create false orifices.

Morphometric measurements of the idiomorphic holotype, including computation of a centreline and smallest radius at each increment of the centreline, yield a total length of the tunnel of $129 \mathrm{~mm}$ at a maximum extent of $56 \mathrm{~mm}$ and a volume of $50 \mathrm{~mm}^{3}$. The host belemnite is $59 \mathrm{~mm}$ in length and $11 \mathrm{~mm}$ in maximum diameter. The smallest radius of the near-circular proximal tunnel is about $300 \mu \mathrm{m}$ (average of $n=200$ increments) and the tunnel is thus about $600 \mu \mathrm{m}$ wide. The distal tunnel, just before the lance-shaped termination, measures only $180 \mu \mathrm{m}$ in smallest radius $(n=200)$, and thus about $360 \mu \mathrm{m}$ in width, but, including the vane, it is up to more than a millimetre in height. The mean minimum radius across the entire trace is $192 \pm 80 \mu \mathrm{m}(n=9323)$. The paratype trace shows a xenomorphic morphology with a collision and circumnavigation pattern. It measures $27 \mathrm{~mm}$ in maximum extent (fragment only) at a total tunnel length of $101 \mathrm{~mm}$ (including the two dead-end side branches of 7 and $3 \mathrm{~mm}$ in length) and a volume of $22 \mathrm{~mm}^{3}$. The host belemnite fragment of the paratype is $35 \mathrm{~mm}$ in length and $11 \mathrm{~mm}$ in maximum diameter. The acute angle of bifurcations is around 25 to $30^{\circ}$. The mean minimum radius across the entire trace (excluding the proximal part that is not preserved in the belemnite fragment) is $142 \pm 53 \mu \mathrm{m}$ $(n=6278)$.

Type material, locality, and stratum: The holotype (Figs. 7a$\mathrm{d}$ and $8 \mathrm{a}-\mathrm{g}$ ) and one paratype (Figs. 7e-f and $8 \mathrm{~h}-1$ ) are preserved in two rostra of Gonioteuthis quadrata, both collected at the Alemannia quarry of Höver, Germany, from the pillula/senonensis to senonensis zones, Misburg Formation, lower Campanian, Upper Cretaceous. Holotype and paratype are housed in the trace fossil collection at the Senckenberg Institute in Frankfurt a. M., Germany (inventory numbers SMF XXX 885 and SMF XXX 886, respectively).

Additional material: Additional material is kept in the private collection of P. Girod and comprises six specimens in topotypical belemnites (including those illustrated in Fig. 7g-h, o), two specimens from the upper Campanian of Misburg, two specimens from the upper Campanian of Kronsmoor (including that in Fig. $7 \mathrm{~m}-\mathrm{n}$ ), and seven specimens from the lower Maastrichtian of Rügen (including those in Fig. 7i-1). All of these records are from northern Germany; they are complemented by a single specimen 


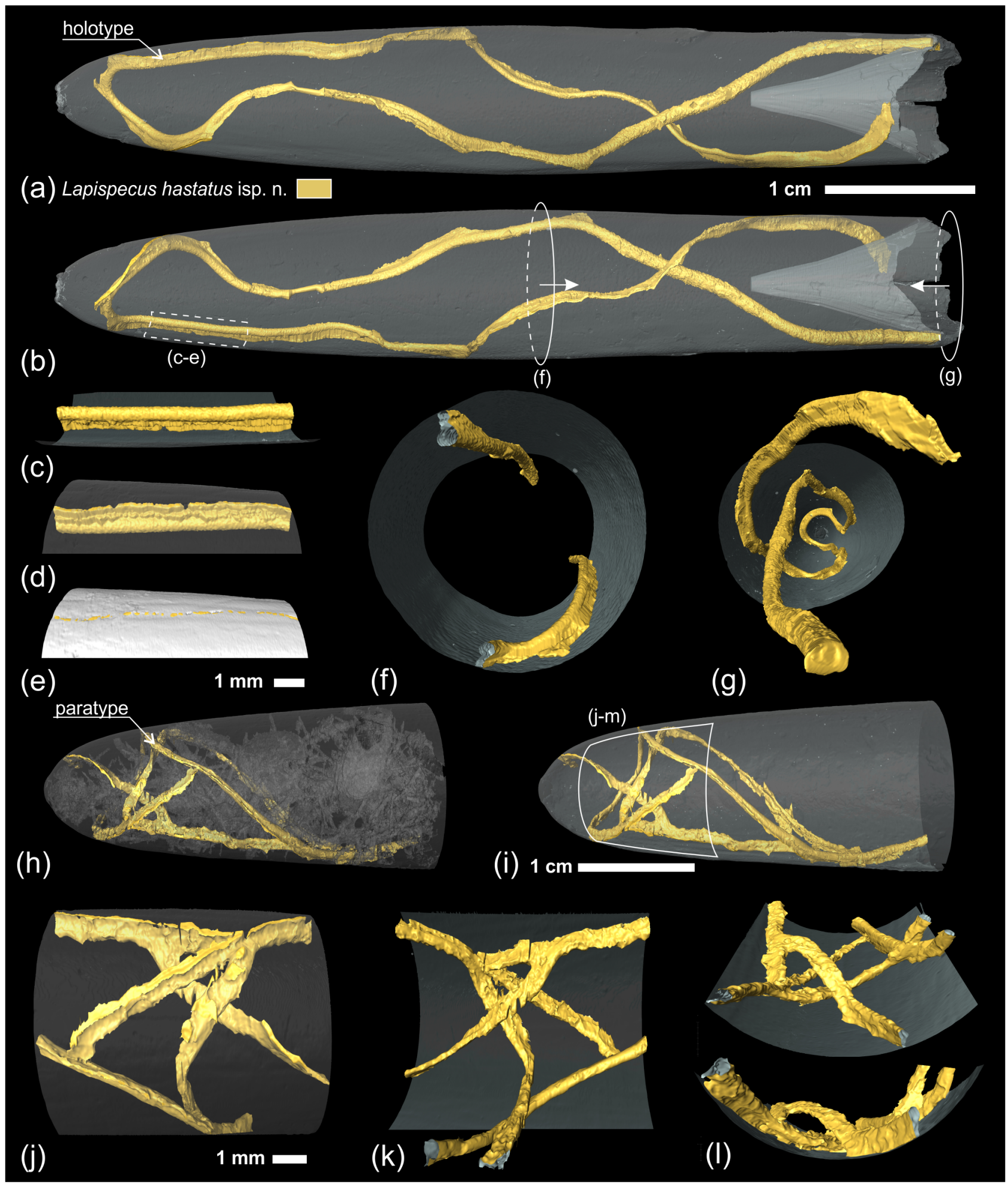

Figure 8. Micro-CT scans of the holotype (a-g) and paratype (h-l) of Lapispecus hastatus isp. n. in guards of Gonioteuthis quadrata from the lower Campanian of Höver, Germany. (a-b) Opposite views of the holotype trace in the belemnite. (c-d) Representative segment seen from inside and outside. (e) Dashed line of openings where the vane connects to the surface. (f) Slice of central rostrum with proximal (top) and distal (bottom) segments with keyhole-shaped cross section. (g) Front view (surface partly cropped) featuring the circular entrance and the lance-shaped termination of the trace. (h-i) The paratype in a belemnite fragment with and without visualisation of the intense bioerosion. (j-l) Diagnostic collision, branching, and circumnavigation pattern. 


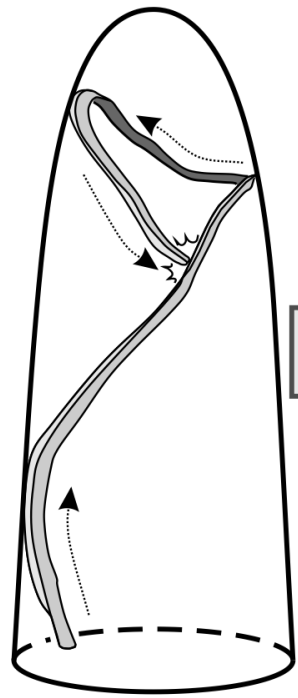

(a)

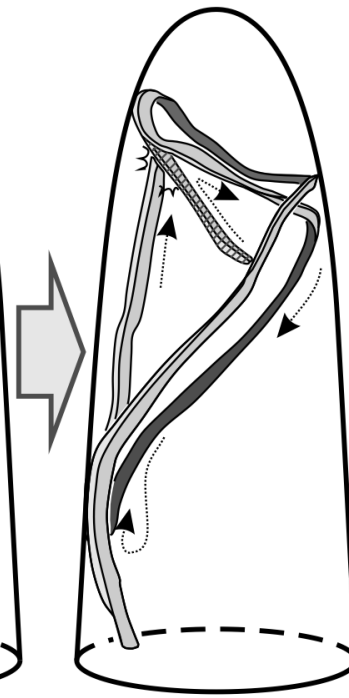

(b)

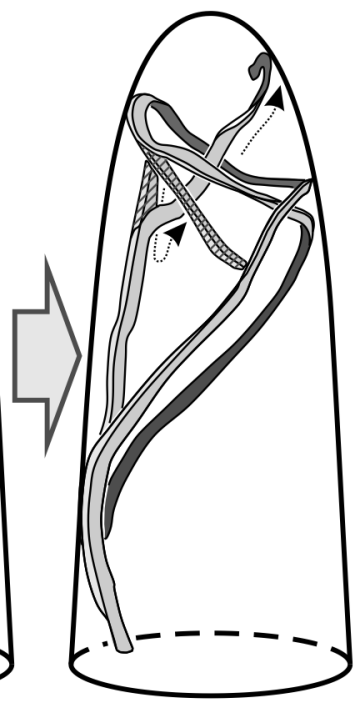

(c)

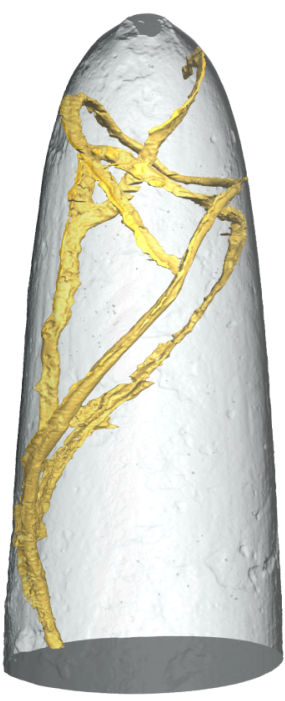

(d)

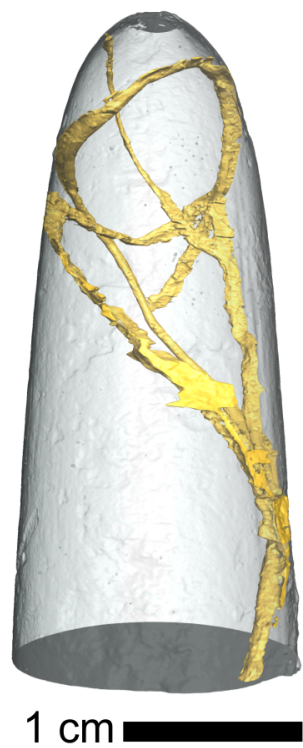

Figure 9. Reconstruction of the temporal development of the paratype of Lapispecus hastatus isp. n. (a) Proximal trace originating somewhere at the front of the belemnite guard and running closely parallel to the substrate surface to near the apex, spiralling back, and hitting its own tunnel. (b) After retreating a little way, leaving a blind termination (false branching), a new (true) branch is formed under an acute angle, delving deeper into the substrate in order to circumnavigate the obstacle, but after another winding colliding again with its own tunnel. (c) Repetition of the retreat-and-branching pattern and lance-shaped termination near the apex of the belemnite. (d) Opposite views of the respective belemnite fragment.

from the upper Maastrichtian at Eben-Emael in Belgium. Accordingly, the known stratigraphical range is lower Campanian to upper Maastrichtian (Upper Cretaceous).

Remarks: Distinguished from the type ichnospecies $L$. cuniculus in that the vane never develops between the limbs of windings but always exclusively between the tunnel and the surface only, and by the vane generally being less than the entrance tunnel diameter in height. Further distinctions are the blade-shaped gallery termination and the presence of blind endings and true branching where the tunnel hits and circumnavigates a pre-existing boring.

\subsection{On the palaeobiology and identity of the trace maker of Lapispecus hastatus isp. $n$.}

Both L. cuniculus and L. hastatus isp. n. were produced in dead substrates, i.e. lithoclasts and belemnite guards, respectively. The architectural design of Lapispecus differs markedly from the most closely related ichnogenera Caulostrepsis and Maeandropolydora. This is primarily because the producer of Lapispecus formed only a single main opening (i.e. the aperture of the main tunnel), whereas in the other two ichnogenera two apertures are developed that may or may not be connected by a spreite to form a single figureof-eight-shaped orifice. The latter case is most prominent in Caulostrepsis and indicates that the trace maker formed the entrance and exit of the tunnel during early ontogeny and successively deepened and widened the tunnel by transverse progression, thereby enlarging the spreite. Using the term "spreite" in this context presumes inclusion of such structures that are not filled with sediment, as it would be the case in soft-bottom dwellings, but are formed by the same transverse progression (for contributions to this debate, see Reis, 1910, and Knaust, 2013). In contrast, the vane in Lapispecus is definitively not a true spreite, but a structure that connects the main tunnel to the surface. Hence, the tunnel was formed not by transverse progression, but by frontal boring, following a course that was more or less parallel to the substrate surface. The vane and its minute openings to the substrate surface could have aided water circulation in the tunnel, thereby assuring ventilation by oxygen-rich water and avoiding local hypoxia. The most proximal part of the tunnel does not sport the vane (or only a widely intermittent one), suggesting that water circulation was not necessary for the relatively short tunnel during the early growth stage. For the development of the distal parts of the long tunnel, however, such ventilation might have been an essential prerequisite, in view of the lack of a second aperture. This morphological circumstance implies that the trace maker of Lapispecus most likely had a body plan in which the mouth and anus were located at the worm's anterior (i.e. in the present case the end that faced the main aperture). This differs from the body plan of a polychaete worm (i.e. mouth and anus at opposing ends), which are held responsible for Caulostrepsis and Maeandropolydora (e.g. Bromley, 1970). Instead, the single entrance is 
in good accordance with the body plan of either a sipunculan (the so-called "peanut worms"; > 100 extant species), or a phoronid (the so-called "horseshoe worms"; $\sim 10$ extant species), which are herein proposed as most probable candidate producers of the two ichnospecies of Lapispecus. While sharing some general features of their body plan, these two groups in part have a very different anatomy and ecophysiology, but for both phyla plausible mechanisms of producing and inhabiting a Lapispecus boring can be inferred from their extant representatives, as outlined in the following account.

In consideration of the tapering shape of the main tunnel, one can argue that it is unlikely that the worm was able to move freely back and forth in its tunnel and may have rather tightly filled out the excavation on a permanent basis. This would agree with a sipunculan trace maker, whose trunk permanently fills out the better part of its excavation, held in place with its body wall musculature acting as a hydrostatic skeleton and a variety of hooks, spines, and papillae embedded in their leathery skin (Warme, 1975; Cutler, 1994). Only a highly flexible introvert was expandable and retractable (Cutler, 1994). The anus is located at the anterior end of the trunk, while the mouth is situated at the tip of the introvert and may bear an elaborate tentacular crown that supports filter or deposit feeding, or posteriorly curved hooks that support "grazing" of the surrounding substrate surface (Cutler, 1994). The ability of sipunculans to bioerode is well known; they may form a significant component of bioeroder communities (e.g. Bromley, 1970; Warme, 1975; Cutler, 1994; Hutchings and Peyrot-Clausade, 2002; Antonelli et al., 2015). Mechanical and chemical mechanisms of bioerosion, or a combination of these, have been advocated (for reviews, see Rice, 1969; Bromley, 1970; Williams and Margolis, 1974). According to Rice (1969) and Cutler (1994), the morphology of Recent borings from which sipunculans were extracted and identified include a range of short cylindrical borings to long, much narrower, and occasionally exceedingly winding tunnels. There is one record of sipunculans from within a branched tunnel system (Warme, 1970), but those might have represented secondary nestlers that merely modified a pre-existing boring (Warme and Marshall, 1969).

The location of the entrance within the alveolus of the belemnites provides some protection from predators, in addition to an operculum-like anterior shield that, according to Cutler (1994), plugs the aperture of some bioeroding sipunculans. This might have been of significant advantage when the belemnite was moved around on the seafloor by hydrodynamic forces, with an entrance in the alveolus more likely to remain above the sediment-water interface, in contrast to an entrance on one side of the belemnite. The same line of reasoning was also followed in the case of another closely related bioerosion trace fossil, namely Trypanites mobilis Neumann et al., 2008, that co-occurred with L. hastatus isp. n. in the Late Cretaceous chalk basin of northern Europe. In that particular case, also a sipunculan was thought to be the most likely candidate trace maker; the preferred use of elon- gate to spherical substrates (i.e. echinoid spines and sponges, respectively) was interpreted as a mobile domicile and an alternative to the conchicolous live habit that is well documented for extant sipunculan worms (Neumann et al., 2008). The similarities between these two cases extend to the fact that the observed morphological and deduced behavioural patterns infer that the two sipunculan trace makers would have had a remarkable ability to recognise the shape of the host substrate and boring orientation. It is conceivable, albeit admittedly speculative, that the trace maker of $L$. hastatus isp. n. was guided to some degree by the regular radial pattern of the calcite crystallites in the belemnite guard, or by the growth increments, which were more prominent prior to partial recrystallisation during earliest diagenesis and which have recently been proposed to have had considerable primary pore space filled with body fluid or organic compounds (Hoffmann et al., 2016). A quite different, but similarly radial and porous, skeletal architecture is rendered by the stereom of regular echinoid spines, the preferred substrate of the trace maker of T. mobilis. In both cases the sipunculans would have chosen a preferred location for the entrance and followed a preferred direction of penetration. Furthermore, both would have been able to detect the stage at which the boring almost completely penetrated the substrate or into a pre-existing excavation, in order to terminate their boring activity (Neumann et al., 2008). In the case of L. hastatus isp. n., this ability goes even further to include an effective strategy to circumnavigate the obstacle. In this context, the vane, in $L$. hastatus isp. n., could also reflect a measure of probing what lies ahead (e.g. an obstacle or the substrate surface), in order to adjust the boring behaviour accordingly. In some cases, this is also suggested by the pointed orientation of the intermittent vane in the direction of growth (e.g. Fig. 7i-j), which can lead to the impression of short side branches formed by abandoned gallery terminations, such as interpreted by Hillmer and Schulz (1973: fig. 7), who considered the specimen in question to be an atypical example of $T$. solitarius. The conspicuous branching behaviour, when circumnavigating an obstacle, is remarkable and allows the deduction that the trace maker had no interest in terminating the tunnel, or lacked the ability to continue frontal progression by making a very sharp turn. Where a Lapispecus hits its own tunnel under an acute angle, abrupt turns of up to about $75^{\circ}$ were observed (e.g. Fig. 7o). Where the obstacle was hit in a more frontal direction, however, the worm chose to retreat a certain distance, and to circumnavigate the obstacle by making only a slight turn of 25 to $30^{\circ}$, allowing better mobility and a more linear body arrangement in its excavation. Whether the blind branch was filled with sediment, or simply cut off by means of an organic wall lining, remains speculative.

The bioerosion process of the circular main tunnel can easily be envisaged to be the result of a rotation of the posterior part of the worm, supported by rigid papillae in the skin of the trunk and/or a posterior caudal shield of horny protein, such as in the sipunculan genus Aspidosiphon (for illustra- 
tions, see e.g. Antonelli et al., 2015). This would have been a drilling process sensu stricto, perhaps supported by chemical weakening of the substrate via secretory products of epidermal glands, such as already reported by Rice (1969). However, an unresolved matter is the question how a sipunculan trace maker would have been able to form the vane and the lance-shaped termination, requiring some type of specialised organ, such as a tail-like caudal appendage that is significantly smaller in diameter than the trunk and according to Cutler (1994) is developed in a number of (non-bioeroding) extant sipunculan genera such as Golfingia and Nephasoma. Alternatively, targeted chemical dissolution would need to be proposed to explain the formation of these asymmetrical features of Lapispecus, but given the limitations of the body fossil record and lack of deduced physiological knowledge on Cretaceous sipunculids, a more detailed identification seems unfeasible at this stage. A trace formation with the anterior introvert, such as proposed by Warme (1975) and others, would require repeated vacation of the boring and repositioning, which appears awkward and would have left the animal exposed to predators. In concord with Rice's (1969) analysis, this explanation is herein considered less likely. A mechanism to allow the proposed ventilation of the tunnel, however, can be named, because there is irrigation by muscular means, which has been observed in some sipunculans and interpreted as an aid to respiration by maintaining oxygen-rich water around the body within the shelter (Cutler, 1994).

Notwithstanding the plausibility of the above interpretation in support of a sipunculan trace maker, the second potential group of trace makers within the drawer labelled "bioeroding worms" that could have produced the two Lapispecus ichnospecies is phoronid worms. Unlike sipunculans, phoronids move freely within a chitinous tube and they possess a lophophore (for filter-feeding) at the anterior end of their body, with a mouth opening within and the anus next to the lophophore (see Emig, 1982, for a review). Phoronids reproduce by sexual means, lay eggs, and release larvae, but the majority of extant phoronid species can also divide asexually by transverse fission, occasionally leading to clusters with high numbers of individuals (Emig, 1979, 1985). Only a single species, i.e. Phoronis ovalis Wright, 1856, is known to also reproduce asexually by means of budding and autotomy of the lophophore (Emig, 1979, 1985), thereby forming pseudo-colonies that are reminiscent of the branched bioerosion trace fossil Talpina ramosa (such as preserved in the "Morris belemnite"; fig. 5a-d) and related ichnotaxa in this ichnogenus (e.g. Voigt, 1972, 1975; Plewes, 1996). Among other modern phoronid species, at least three are known to bioerode solitary tubes into hard substrates (Emig, 1982, 1985), but the link between certain extant phoronid species and the morphology of their traces has only been explored cursorily, and the interpretation of fossil phoronid bioerosion traces remains speculative on account of a lack of body fossils (Emig, 2010 and personal communication).
As far as the process of bioerosion is concerned, we can envisage the following scenario for $L$. hastatus isp. n., which would also be largely compatible with $L$. cuniculus: the phoronid larva allowed colonisation of a scattered belemnite rostra in the vast chalk sea, and upon metamorphosis developed into the actual phoronid worm that could have chosen a site near to or within the alveolus for initialisation of the bioerosion process. This could have been a combination of chemical dissolution or weakening of the belemnite substrate, and mechanical force exerted by muscle-powered hydraulic pressure changes in the posterior ampulla, analogous to the burrowing process of phoronids in soft grounds (see Emig, 1982, fig. 27). This frontal and linear bioerosion process could explain the asymmetrical cross section of the circular tunnel and its vane, as opposed to mechanical drilling by rotation as seen in sipunculids. Thereby, the phoronid would have been guided (as also proposed above for a sipunculan trace maker) by the probing vane in combination with the concentric architecture of the belemnite's microstructure. A preferred orientation of phoronid borings along shell layers has also been noted by Emig (1982). The tube was lined with a chitinous wall, except for the site of bioerosion progress, and the phoronid worm could freely move in this tunnel (Emig, 1982). This movement, in addition to cilia in the epidermal cells, would also have assured ventilation within the tube (Emig, 1982). The disposal of the mechanically eroded belemnite carbonate, however, would not have required transport along the animal's body through the entire length of the boring (given that ingestion and excretion is not an option when mouth and anus are positioned anteriorly), but could have been achieved in a more efficient way. This is a pumping process achieved by the posterior ampulla that sealed off the distal tunnel and pushed the water, together with the carbonate particles, out through the vane and the small perforations on the substrate surface. Quite possibly, this process was directly linked to the hydrostatic forcing during the bioerosion process (see above). Furthermore, this interpretation would imply that only the most distal openings to the substrate surface would have had to be kept open, while the more proximal ones would have been closed by the formation of a chitinous wall lining, thereby taking advantage of prohibiting unwanted intrusion of chalk sediment. This line of reasoning would favour a phoronid as the trace maker, rather than a sipunculan that could also have applied hydrostatic pumping, but probably less effectively considering the lack of an ampulla, and would not have had such an efficient way of sealing off the more proximal surface apertures. In the case of a phoronid trace maker, the distal opening to the substrate surface allows an elegant solution for another situation, namely predatory attacks or any other irritation to the anterior tentacles and lophophore that would require a rapid retreat into the tube. In this case, the distal aperture to the substrate surface would have served as a valve for the water in the distal part of the tunnel that could have accelerated pressure equilibrium. The resultant jet of 
water ejected from within the tunnel would have also been effective in those instances where the active surface apertures were located within the chalk sediment, which is an unavoidable scenario at least for $L$. hastatus isp. n., considering the spiralling orientation of the tunnel around a belemnite that most probably was sunken into the soft carbonate ooze to some degree.

In conclusion, actualistic data based on the anatomy and ecophysiology of extant representatives of sipunculan and phoronid worms, combined with deductions about the morphology of the bioerosion traces, provide plausible models for the formation of Lapispecus bioerosion traces for both principal groups of bioeroding worms. We here refrain from favouring either one of these two options.

\subsection{The new bioerosion trace fossil Entobia colaria}

The third and final case study is a new sponge boring with some resemblance of the classic Entobia cretacea Portlock, 1843, the lectotype of which is also preserved in an Upper Cretaceous (probably Campanian) belemnite guard (for a revision of this ichnospecies, see Bromley, 1970). A diagnostic feature of the new ichnospecies described herein that is developed neither in E. cretacea nor in any other ichnospecies of Entobia is the appearance of sieve-shaped orifices on the surface with a very irregularly lobed outline or a cluster of several small, asymmetric openings that lend it a grated appearance. The micro-CT analysis of the holotype is a good example of algorithm-based segmentation not used for the distinction of different bioerosion traces, but for the separation of the individual chambers within a single three-dimensional bioerosion network. This has served as a basis for morphometric analyses of the 114 detected individual chambers. This approach enhances the morphological description, in a way that would not have been possible with conventional methods.

\section{Entobia Bronn, 1837}

Type ichnospecies: Entobia cretacea Portlock, 1843 by subsequent designation of Häntzschel (1962).

Diagnosis: Boring in carbonate substrate comprising a single chamber or networks or boxworks of chambers or non-camerate galleries, connected to the substrate surface by several or numerous apertures. The galleries show increase in size during growth; in some forms, inflation at more or less regular distances produces a system of closely interconnected chambers; in other forms chambers lie distant from one other; in still other forms no cameration develops. The boring surface of most forms bears a cuspate microsculpture. Fine pioneer (exploratory) threads are usually present, arising from all or some surfaces of the system. Apertural canals lead to apertures (in- and exhalent pores). [Emended diagnosis taken from Bromley et al., 2009]
Entobia colaria isp. $\mathbf{n}$.

Figs. 10-11

2013 Entobia cretacea - Girod and Rösner: 281, fig. 3

Etymology: From colare (Latin, meaning filtering, clearing, straining) in allusion to the presumed function of the diagnostic character, i.e. the grated apertures or pore sieves, and also to the filter-feeding activity of the trace-making excavating sponges.

Diagnosis: Three-dimensional network of sub-spherical chambers, polygonal where most crowded, only rarely fused, connected by numerous short and slender, cylindrical intercameral canals. Apertural canals short, leading either to small circular surface apertures or to distinctly larger and irregular apertures or clusters of smaller openings on substrate surface, resembling grated orifices.

Description: In the holotype and all other specimens studied, E. colaria isp. n. is characterised by a dense three-dimensional cameration, with individual polygonal chambers of varying size being separated by substrate walls relatively constant in thickness (Figs. 10-11). These walls are penetrated by numerous short intercameral canals with circular cross section that connect the individual chambers (e.g. Figs. 10e-g, i and $11 \mathrm{f}-\mathrm{h}$ ). In addition, short, unbranched and pointed exploratory threads probe the substrate (Fig. 10i). The surfaces of the chamber walls bear the characteristic cuspate microtexture with erosion scars of about 20 to $30 \mu \mathrm{m}$ in diameter (Fig. 10i). Some of the apertural canals appear densely clustered (Fig. 10f), whereas others widen or branch towards the substrate surface (Fig. 10h). In consequence, the orifices on the surface of the belemnite guards are not circular, such as in other entobians, but very irregular in outline, often complex and lobed, or forming a cluster of several small circular to asymmetrical openings, appearing grated or sieve-like (Figs. 10a-d and $11 \mathrm{a}-\mathrm{d})$. In between these comparatively large orifices, there are scattered circular openings that are much smaller in dimension (Fig. 10c-d). In the holotype and several other specimens, the apertures are overprinted by radial Gnathichnus pentax grazing/predation traces (oriented around the apertures) produced by regular echinoids or by subparallel scratch marks probably left by fish (Figs. 10b, j-k and 11a). A single specimen was found eroded or bitten and entirely opened on one side (Fig. 101-m). The holotype belemnite measures $62 \mathrm{~mm}$ in length and $14 \mathrm{~mm}$ in maximum diameter and has a total volume of $7471 \mathrm{~mm}^{3}$. Remarkably, $4627 \mathrm{~mm}^{3}$ (or $62 \%$ ) of this volume is occupied by the holotype trace of E. colaria isp. n. The segmentation algorithm identified a total of 114 individual chambers that, according to shape analysis, range in volume from 1 to $150 \mathrm{~mm}^{3}$ with a mean of $41 \pm 32 \mathrm{~mm}^{3}$. Their maximum diameter is 3 to 


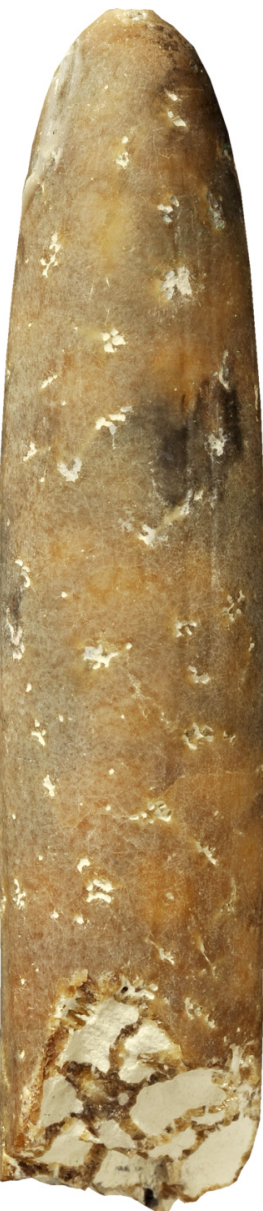

(a) $5 \mathrm{~mm}$

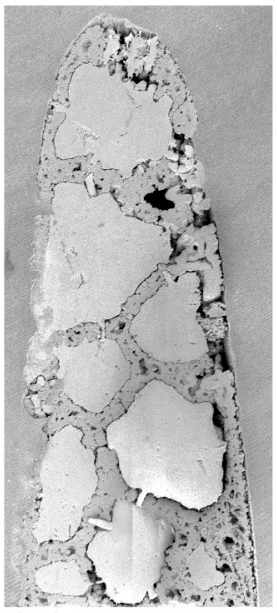

(g)

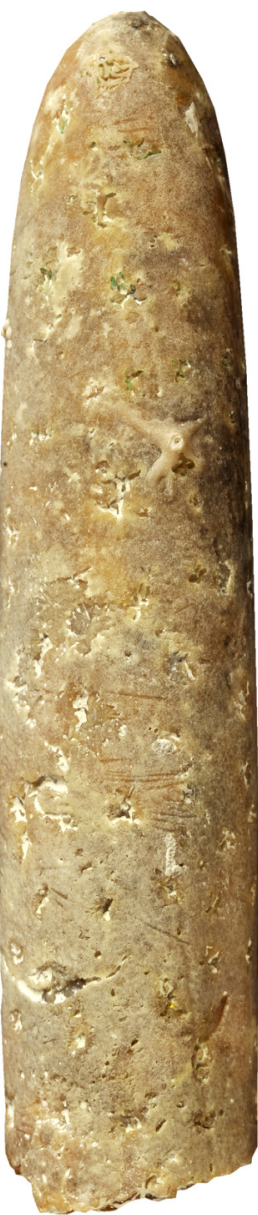

(b)

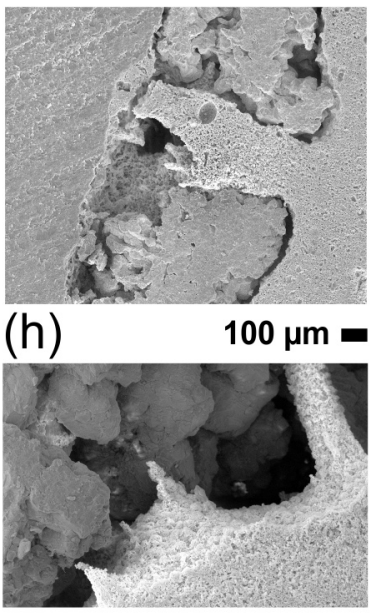

(i)

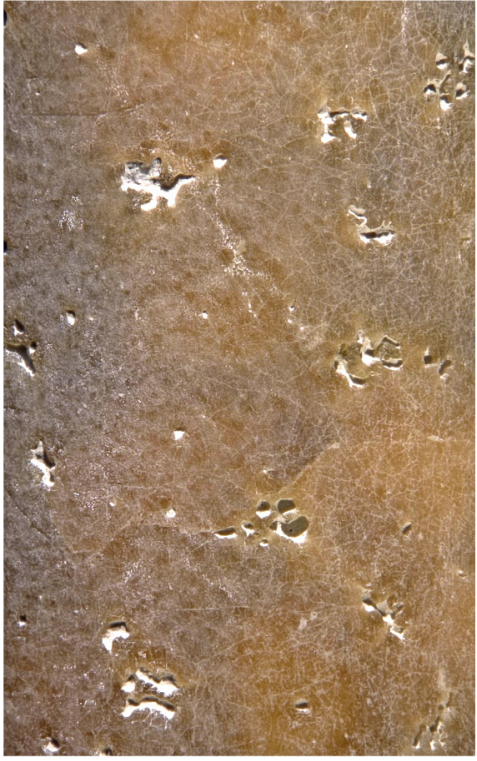

(c)

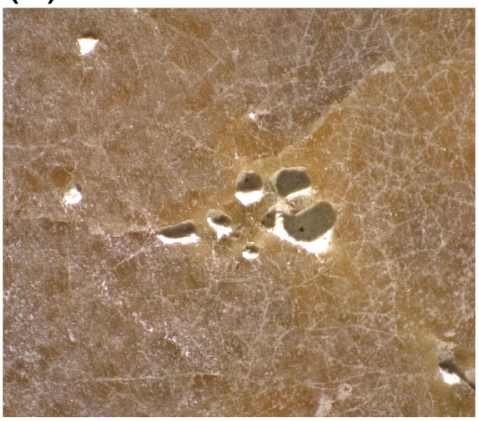

(d)

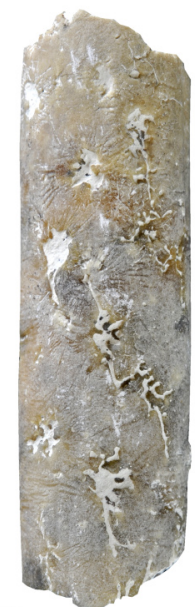

(j) $5 \mathrm{~mm}$ (k)

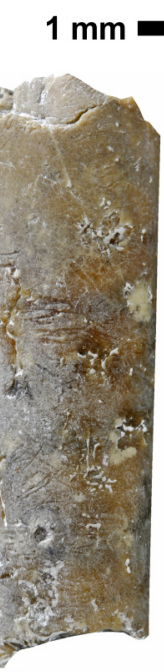

$1 \mathrm{~mm}=$ (e)

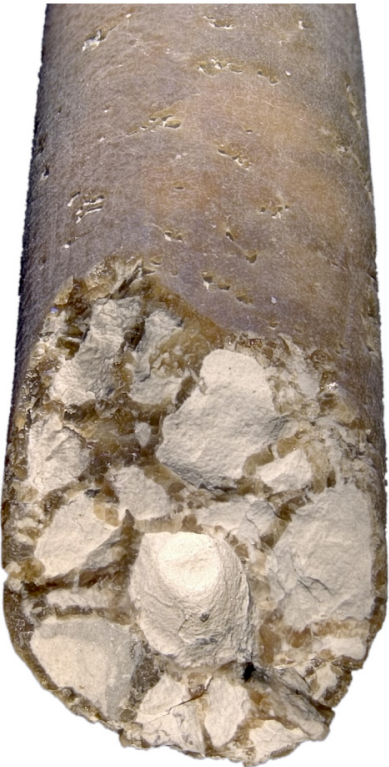

$1 \mathrm{~mm}$

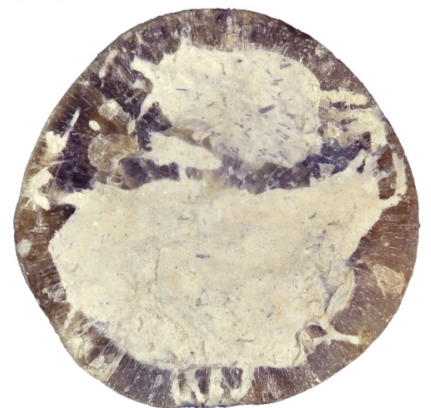

(f)

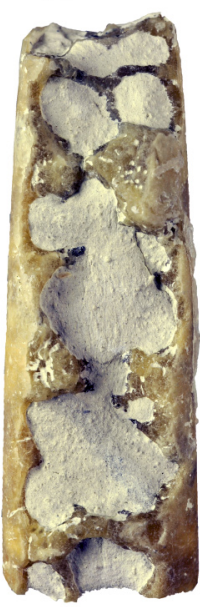

(I) $5 \mathrm{~mm}$
$1 \mathrm{~mm}$

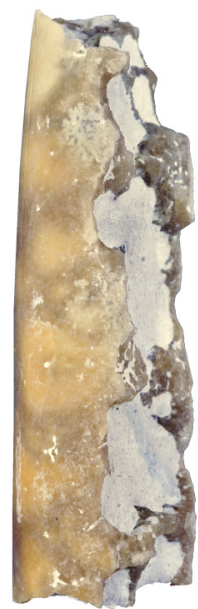

(m)

Figure 10. Entobia colaria isp. $n$. in belemnite rostra from the lower Campanian of Höver (a-k) and Misburg (l-m), Germany. (a-b) Lateral views of the specimen of Gonioteuthis quadrata that bears the holotype. (c-d) Enlargements of the holotype, illustrating the diagnostic sieveshaped apertures. (e) Broken area around the alveolus with thin intercameral walls and canals. (f) Cross section through another specimen showing clustered and fused canals that lead to the surface apertures. (g) SEM image of a resin cast showing a high degree of silicification that led to incomplete dissolution of the walls in $\mathrm{HCl}$. (h) Detail showing a ramifying apertural canal (left is outside). (i) Detail illustrating a connecting canal on the right and the typical cuspate surface texture. ( $\mathbf{j}-\mathbf{k})$ Both sides of a specimen with strong signs of predation/grazing by regular echinoids (Gnathichnus pentax around apertures) and fish (subparallel scratches). (1-m) Specimen completely eroded on one side and open. 

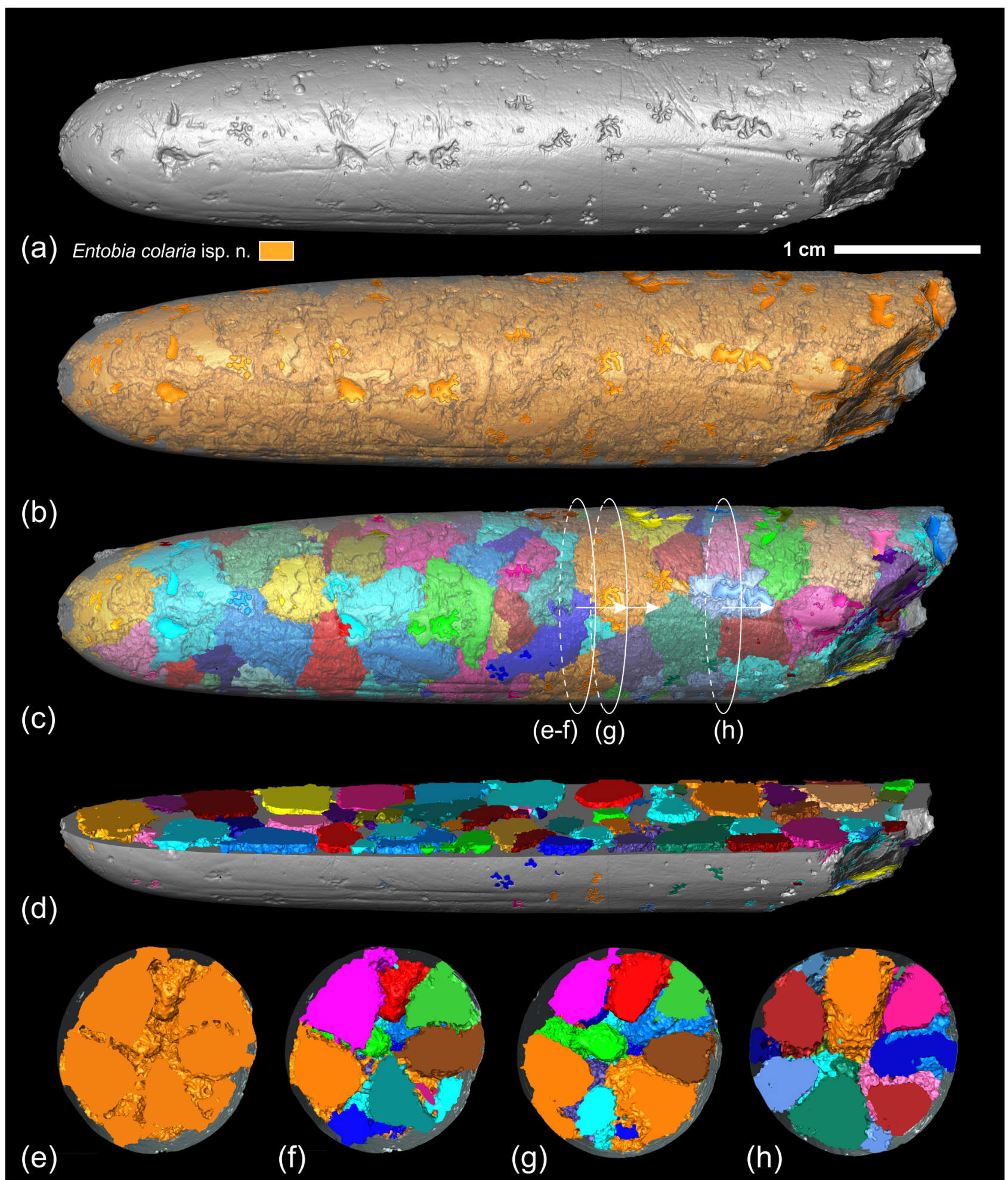

Figure 11. Holotype of Entobia colaria isp. n. in a guard of Gonioteuthis quadrata from the lower Campanian of Höver, Germany. (a) Surface of belemnite illustrating the diagnostic sieve-shaped apertures, some of which are enlarged by the echinoid grazing/predation trace Gnathichnus pentax. (b) The holotype occupying $62 \%$ by volume of the belemnite guard. (c) Algorithm-based separation of the individual chambers. (d) Surface and trace cut open. (e-h) Three different cross sections, the first with and without chamber separation. 
$14 \mathrm{~mm}$, with a mean of $7 \pm 2 \mathrm{~mm}$. The mean anisotropy of the 114 chambers is $0.7 \pm 0.1$ and the elongation is $0.5 \pm 0.2$.

Type material, locality and stratum: The holotype (Figs. 10a$\mathrm{e}$ and 11) is preserved in an Upper Cretaceous (lower Campanian, Emscher Formation, lingualquadrata Zone) belemnite guard of the species Gonioteuthis quadrata from the Alemannia quarry at Höver, Germany. It is reposited in the trace fossil collection at the Senckenberg Institute in Frankfurt a. M., Germany (inventory number SMF XXX 887).

Additional material: Specimens contained in the private collection of $\mathrm{P}$. Girod comprises four specimens in topotypical belemnite guards (including those in Fig. 10f-i and $\mathrm{j}-\mathrm{k}$ ) and three specimens from the lower Campanian of Misburg, Germany (including the one in Fig. 101-m). The known stratigraphical range is thus presently limited to the lower Campanian.

Remarks: Overall, E. colaria isp. n. was found to be most closely similar to E. cretacea. However, the diagnostic character of the sieve-shaped orifices at the substrate surface is unknown in E. cretacea and any of the other ichnospecies of Entobia. Although of limited ichnotaxonomic relevance, it should be noted that the dimension of the etching scars appears to be smaller in E. colaria isp. n. $(20-30 \mu \mathrm{m})$ in comparison to $E$. cretacea $(25-60 \mu \mathrm{m})$. The diameter of the chambers is considerably larger in E. colaria isp. n. (3-14 mm; mean 7 $\pm 2 \mathrm{~mm}$ ) than in E. cretacea $(1.5-4 \mathrm{~mm})$, resulting in a much larger chamber-versus-scar size ratio in the new ichnospecies. We conclude that E. colaria isp. n. is distinct from $E$. cretacea and other presently known Entobia ichnospecies.

\subsection{On the palaeobiology and identity of the trace maker of Entobia colaria isp. $n$.}

The exhalant pores (oscula) of many sponges are wider than the inhalants and can be raised above the surface. They bundle the water from different exhaling canals to result in a single jet that is ejected from the sponge (De Vos et al., 1991). Here, the main effect and function is to achieve increased velocities that will remove the wastewater as far as possible from the sponge surface and thus avoid re-inhaling. Inhalant structures often display the exact opposite morphological principle: the diameters of the inhalant pores (ostia) can be significantly reduced by tissue features that subdivide the openings or by replacing a single larger opening with several smaller ones (occasionally referred to as cribriform papillae or as pore sieves; see Carter, 1879 and Rützler, 2002). The limited diameter of these inhalant pores will reduce the incurrent speed and regulate the maximum particle size that can enter the sponge's canal system, thus providing an efficient filter that helps avoiding the intake of sediment grains and other unwanted particles that can clog the sponge's circulation system and compromise vital functions (Yahel et al., 2006; Bell et al., 2015; Schönberg, 2016). As far as the bioeroding sponges are concerned, this applies to all species of the genera Cliona, Cliothosa, Spheciospongia, and Siphonodictyon (see e.g. De Vos et al., 1991; Schönberg, 2000; Rützler, 2002). In many Clionaida the pores are contractile (Emson, 1966; Strehlow et al., 2016), or are protected by a palisade of spicules (De Vos et al., 1991; Rützler, 2002; Schönberg, 2015), allowing further control of what will enter the sponge.

Corresponding intake- or flow-controlling cribriform structures that are developed not by means of tissue organisation but as a bioerosion structure in the calcareous substrate exist, but these have previously been overlooked or have not received much attention. Prior to the present study, such structures had been noted for the extant IndoPacific Siphonodictyon paratypicum (Fromont, 1993) and Siphonodictyon diagonoxeum(Thomas, 1968). However, in these cases, perforated domes of remnant substrate protrude into the erosion chambers and cover the mouths of the canals like thimbles that strain the water (Thomas, 1968; Schönberg and Tapanila, 2006). Schönberg and Tapanila (2006) proposed the Devonian sponge boring E. devonica (Clarke, 1921 ) as the closest extinct match for $S$. paratypicum. However, the internal thimble-like pore sieve they described for the extant sponge was not observed in any of the hundreds of specimens that those authors studied. Structures at the substrate surface similar to the ones described here were previously unknown and are thus only based on trace fossils. Nevertheless, the sieve-like erosion on the belemnite surface at the location of the former papillae of the trace maker of $E$. colaria isp. $\mathrm{n}$. is here interpreted as another type of filtering device.

An alternative interpretation, albeit ultimately implying a related function, would be that the grated surface apertures were not developed at the proposed inhalant ostia but in actual fact constitute an expression of the exhalant oscula and that, instead, the much smaller circular apertures in between served as inhalant pores. Such an interpretation would be in line with the general observation that in bioeroding sponges inhalant pores are usually smaller than exhalent ones (De Vos et al., 1991; Rützler, 2002). This line of reasoning is furthermore supported when considering that a substantial part of the belemnite probably was sunken into the soft marly ooze, as is reflected by the fact that often the side of the belemnites that bear E. colaria is well preserved, while the other shows distinct signs of attack by grazing echinoids (producing $G$. pentax, often focused specifically on the surface apertures) and fish (producing larger and subparallel scratch marks). A similar deduction was made by Radwański (1972) on the basis of clustering of other bioerosion traces, and particularly the very common traces of the ichnogenus Dendrina, on just one side of chalk belemnites. According to our observations, Radwański's observations also hold true for the early Cam- 
panian belemnites in which dendrinids and other bioerosion trace fossils are often concentrated on one side. A number of further faunal as well as sedimentological investigations also suggest a soft seafloor for the lower Campanian marl facies and a more stable soft-bottom consistency in the case of the carbonate ooze of the Maastrichtian chalk facies (e.g. AbuMaaruf, 1975; Surlyk and Birkelund, 1977; Niebuhr, 1995; Neumann, 2000; Niebuhr et al., 2007). Occurrences of hardgrounds, other than small benthic islands provided by the belemnites themselves and other biogenic skeletons scattered on the seafloor, can thus not to be expected for the palaeoenvironment of the Campanian of northern Germany. Since the grated apertures of E. colaria isp. n. are developed on either side of the belemnite guards, a substantial number of them were probably in contact to the soft sediment, where they were in danger of becoming clogged with sediment particles. In this case, the grated nature of the apertures could have been of an advantage not only for inhalant pores but also for the larger exhalent ones. As far as extant excavating sponges are concerned, the occurrence of pores exhaling into the sediment is known, for instance, for psammobiontic forms (Schönberg, 2016). However, the morphology of E. colaria isp. n. points towards a so-called alpha form (for a review, see Schönberg et al., 2017), which in extant excavating sponges, and particularly in Siphonodictyon, are usually characterised by short papillae and are regarded by sponge workers as little tolerant of sediment contact or burial (Schönberg, 2016 and personal communication, 2017). At present, this contradiction cannot be resolved. As for those pores that reached above the sediment-water interface, however, the grated nature of the apertures could have provided additional benefit of an effective mechanism for protecting the endolithic parts of the sponge tissue from gazing pressure.

Independent of the actual function, only speculations with an actualistic perspective in mind are possible. Those unique perforations at the substrate surface are here defined as primary diagnostic feature that separates E. colaria isp. n. from all other ichnospecies of Entobia. This includes the one with the closest similarity in globular chamber arrangement, E. cretacea, the pores of which were diagnosed by Bromley (1970) as "surface pores, one to four per chamber, are fine $(0.15$ to $0.7 \mathrm{~mm})$ ", without mention of perforate substrate structures. For some entobians, the rare occurrence of "fused" surface apertures was noted by Bromley and D'Alessandro (1984) for E. geometrica Bromley and D'Alessandro, 1984, E. laquea Bromley and D'Alessandro, 1984, E. megastoma (Fischer, 1868), E. ovula Bromley and D'Alessandro, 1984, and E. paradoxa (Fischer, 1868). Nevertheless, only in E. colaria isp. n. is the regular occurrence of grated surface apertures a consistent morphological feature that concerns all large pores in several specimens.

Early diagenetic dissolution of the opaline silica that forms the diagnostic sponge spicules prevents identification of most trace makers of fossil entobians. Only a few exceptions to this rule exist, such as recorded by Blissett et al. (2006) and Bromley and Schönberg (2008). The latter record is of particular relevance to the present study, since it also stems from the Cretaceous and involves the morphologically most closely similar entobian, namely E. cretacea, the trace-making sponge of which was described as a new fossil species, Aka akis (now Siphonodictyon akis). It appears likely that species of Siphonodictyon were the producers of both E. cretacea and E. colaria isp. n., considering that (i) Siphonodictyon is known to be well adapted to soft-sediment environments in both shallow and deeper waters (Rützler, 1971; Schönberg, 2016), since (ii) it is the sole known extant genus to form pore sieves as part of their calcareous substrate (Thomas, 1968; Schönberg and Tapanila, 2006), furthermore (iii) acknowledging that relatively large chambers with chamber walls of constant thickness are a typical feature of Siphonodictyon (C. H. L. Schönberg, personal communication, 2017), and (iv) considering the morphological similarity of the cameration pattern between $E$. cretacea and $E$. colaria isp. $\mathrm{n}$.

In fact, it cannot be ruled out entirely that $S$. akis was the trace maker of both E. colaria isp. n. and E. cretacea, in which case the former represents a late developmental stage of the latter. On the one hand, this idea receives support from the fact that all of the eight studied specimens of $E$. colaria isp. n. show a high degree of occupation within its belemnite substrate (i.e. more than two-thirds of the belemnite guard contains Entobia chambers). Also, earlier ontogenetic stages of $E$. colaria isp. n. that would show grated apertures have not been identified to date. Moreover, the fact that the chambers in E. colaria isp. n. are, on average, considerably larger than in E. cretacea could be explained by fusion of several smaller chambers. On the other hand, even though there are at least some cases where extant species of Siphonodictyon develop from one growth type into another (Calcinai et al., 2007), such fusion of chambers would be quite unusual for Siphonodictyon (C. H. L. Schönberg, personal communication, 2017). Furthermore, reports of E. cretacea that completely fill their host substrate are common, but none has been described with grated apertures (see Bromley and Schönberg, 2008, fig. 1B, as a good example), supporting the view that $E$. colaria isp. n. and E. cretacea rather are distinct ichnospecies produced by different trace makers, as proposed above. Hence, until spicule body fossil evidence for $S$. akis can be identified in E. colaria isp. n. borings, or unequivocal early ontogenetic stages of E. colaria isp. n. are recognised, or transitional stages between E. colaria isp. n. and E. cretace $a$ are recorded, the relationship between these two most conspicuous Entobia ichnospecies in Late Cretaceous chalk belemnites remains in part unresolved. 


\section{Conclusions}

Micro-computed tomography (micro-CT) in conjunction with algorithm-based segmentation procedures and morphometric assessments is a prime tool for non-destructive visualisation and analysis of bioerosion trace fossils. This holds true in particular for material that is otherwise inaccessible to the approved cast-embedding technique, as demonstrated by three case studies of bioerosion traces in Late Cretaceous belemnite guards that are either designated types, infilled with lithified sediment, or partially silicified.

The Late Cretaceous belemnite containing the lectotype of Dendrina dendrina (Morris, 1851) was documented to bear a diverse bioerosion trace fossil assemblage, comprising at least 10 ichnotaxa, including Dendrina dendrina, D. lacerata, Entobia isp., Calcideletrix flexuosa, Talpina ramosa, Iramena isp., Ramosulcichnus biforans, Trypanites solitarius, Trypanites isp., and Orthogonum lineare. Despite the high ichnodiversity and abundance, only $1 \%$ of the host belemnite was found bioeroded.

The new tubular and occasionally branched macroboring trace fossil Lapispecus hastatus isp. $\mathrm{n}$. is interpreted as the work of a long and tapering trace maker that penetrated the host substrate from a single circular entrance (with anterior mouth and anus allowing filtering activity under favourable conditions), preferably located in the alveolus of belemnites (providing protection from predators and sediment smothering), avoiding breaking through to the substrate surface except for the formation of a thin vane (providing a means to ventilate the long tunnel and to dispose mechanically removed carbonate particles), and with the ability to detect and circumnavigate obstacles by means of retreat and branching. These characteristics are most compatible with a sipunculan or a phoronid worm as the trace maker.

The new camerate network macroboring Entobia colaria isp. $\mathrm{n}$. is interpreted as the work of an excavating sponge, with affinity to a trace maker of the genus Siphonodictyon. It is distinguished from all other entobians by the development of pore sieves at the substrate surface, at the presumed locations of inhalant papillae or at the exhaling pores. This structure is formed by grated apertures in the host substrate, rather than tissue or skeletal architecture. In the holotype of E. colaria isp. n., a total of 68 vol.\% of the host belemnite guard was bioeroded by the sponge, which is probably close to the maximum sustainable bioerosion volume. At present, it cannot be ruled out that $E$. colaria isp. n. is a late developmental stage of $E$. cretacea, both produced by the bioeroding sponge Siphonodictyon akis.

The 3-D models generated by means of X-ray micro-CT of bioerosion trace fossils may serve as so-called cybertypes that complement the physical types and can be studied as a digital facsimile. It is proposed that cybertypes should be recognised by the International Code of Zoological Nomenclature, acknowledging and supporting the growing field of cybertaxonomy.
Data availability. Object files and 3-D PDFs for all of the presented micro-CT scans are reposited at https:// doi.org/10.1594/PANGAEA.875121 (Wisshak et al., 2017a).

Competing interests. The authors declare that they have no conflict of interest.

Acknowledgements. Paul Taylor and Consuelo Sendino (Natural History Museum, London, England) kindly arranged the loan of the Morris belemnite, and Thomas Rösner (Berlin) presented us some material from his private collection on loan. Christian Emig (Marseille, France), Christian Neumann (Museum für Naturkunde, Berlin, Germany) and Christine Schönberg (University of Western Australia, Crawley, Australia) are thanked for discussions on potential phoronid, sipunculan, and sponge trace makers, respectively. Daniel Baum (Zuse Institute, Berlin, Germany) supported the post-processing with Amira. Last but not least we gratefully acknowledge John Jagt (Natuurhistorisch Museum Maastricht, Netherlands) and Martin Rücklin (Naturalis Biodiversity Center, Leiden, Netherlands) for their thorough reviews of this paper.

Edited by: Christian Klug

Reviewed by: John Jagt and Martin Rücklin

\section{References}

Abu-Maaruf, N.: Feingliederung und Korrelation der Mergelkalkfazies des Unter-Campan von Misburg, Höver und Woltorf im ostniedersächischen Becken, Ber. Naturhist. Ges. Hannover, 119, 127-204, 1975.

Adams, T. L., Strganac, C., Polcyn, M. J., and Jacobs, L. L.: High resolution three-dimensional laser-scanning of the type specimen of Eubrontes (?) glenrosensis Shuler, 1935, from the Comanchean (Lower Cretaceous) of Texas: Implications for digital archiving and preservation, Palaeontol. Electron., 13, 11 pp., 2010.

Amon, D. J., Sykes, D., Ahmed, F., Copley, J. T., Kemp, K. M., Tyler, P. A., Young, C. M., and Glover, A. G.: Burrow forms, growth rates and feeding rates of wood-boring Xylophagaidae bivalves revealed by micro-computed tomography, Front. Mar. Sci., 2, 1-13, 2015.

Antonelli, F., Sacco Perasso, C., Ricci, S., and Davidde Petriaggi, B.: Impact of the sipunculan Aspidosiphon muelleri Diesing, 1851 on calcareous underwater cultural heritage, Int. Biodeter. Biodegr., 100, 133-139, 2015.

Bell, J. J., McGrath, E., Biggerstaff, A., Bates, T., Bennett, H., Marlow, J., and Shaffer, M.: Sediment impacts on marine sponges, Mar. Poll. Bull., 94, 5-13, 2015.

Beuck, L., Vertino, A., Stepina, E., Karolczak, M., and Pfannkuche, O.: Skeletal response of Lophelia pertusa (Scleractinia) to bioeroding sponge infestation visualised with micro-computed tomography, Facies, 53, 157-176, 2007.

Beuck, L., Wisshak, M., Munnecke, A., and Freiwald, A.: A giant boring in a Silurian stromatoporoid analysed by computer tomography, Acta Palaeontol. Pol., 53, 147-158, 2008. 
Blissett, D. J., Pickerill, R. K., and Rigby, J. K.: A new species of boring sponge from the White Limestone Group, Jamaica, Caribb. J. Sci., 42, 246, 2006.

Boekschoten, G.: On bryozoan borings from the Danian at Fakse, Denmark, in: Trace fossils, edited by: Crimes, T. P. and Harper, J. C., Geol. J., Spec. Issue, 3, 43-48, 1970.

Bromley, R. G.: Borings as trace fossils and Entobia cretacea Portlock, as an example, in: Trace fossils, edited by: Crimes, T. P. and Harper, J. C., Geol. J., Spec. Issue, 3, 49-90, 1970.

Bromley, R. G.: On some ichnotaxa in hard substrates, with a redefinition of Trypanites Mägdefrau, Palaeontol. Z., 46, 93-98, 1972.

Bromley, R. G.: A stratigraphy of marine bioerosion, in: The application of ichnology to palaeoenvironmental and stratigraphic analysis, edited by: McIlroy, D., 455-481, 2004.

Bromley, R. G. and D'Alessandro, A.: The ichnogenus Entobia from the Miocene, Pliocene and Pleistocene of southern Italy, Riv. Ital. Paleontol. Stratigr., 90, 227-296, 1984.

Bromley, R. G. and D“Alessandro, A.: Bioerosion of the PlioPleistocene transgression of Southern Italy, Riv. Ital. Paleontol. S., 93, 379-442, 1987.

Bromley, R. G. and Schönberg, C. H. L.: Borings, bodies and ghosts: spicules of the endolithic sponge Aka akis sp. nov. within the boring Entobia cretacea, Cretaceous, England, in: Current developments in bioerosion, edited by: Wisshak, M. and Tapanila, L., Springer, Heidelberg, 235-248, 2008.

Bromley, R. G., Wisshak, M., Glaub, I., and Botquelen, A.: Ichnotaxonomic review of dendriniform borings attributed to foraminiferans: Semidendrina igen. nov., in: Trace fossils: concepts, problems, prospects, edited by: Miller III, W., Elsevier, Amsterdam, 518-530, 2007.

Bromley, R. G., Uchman, A., Kolodziej, B., and Kędźierski, M.: Large chambered sponge borings on a Late Cretaceous abrasion platform at Cracow, Poland, Cret. Res., 30, 149-160, 2009.

Bronn, H. G.: Lethaea Geognostica oder Abbildungen und Beschreibungen der für die Gebirgs-Formationen bezeichnendsten Versteinerungen, Band II (pp. 544-768) + Atlas, Schweizerbart, Stuttgart, 1837.

Buatois L. A., Wisshak M., Wilson, M. A., and Mángano, M. G.: Categories of architectural designs in trace fossils: A measure of ichnodisparity, Earth-Sci. Rev., 164, 102-181, 2017.

Calcinai, B., Cerrano, C., and Bavestrello, G.: Three new species and one re-description of $A k a$, J. Mar. Biol. Assoc. U.K., 87, 1355-1365, 2007.

Carter, H. J.: On a new species of excavating sponge (Alectona millari); and on a new species of Rhaphidotheca (R. affinis), J. Roy. Microscop. Soc., 2, 493-499, 1879.

Clarke, J. M.: Organic dependence and disease, their origin and significance, N. Y. State Mus. Bull., 221/222, 1-113, 1921.

Cunningham, J. A., Rahman, I. A., Lautenschlager, S., Rayfield, E. J., and Donoghue, C. J.: A virtual world of paleontology, Trends Ecol. Evol., 29, 347-357, 2014.

Cutler, E.: The Sipuncula - Their systematics, biology and evolution, Cornell University Press, Ithaca and London, 1994.

Davies, T. G., Rahman, I. A., Lautenschlager, S., Cunningham, J. A., Asher, R. J., Barrett, P. M., Bates, K. T., Bengtson, S., Benson, R. B. J., Boyer, D. M., Braga, J., Bright, J. A., Claessens, L. P. A. M., Cox, P. G., Dong, X.-P., Evans, A. R., Falkingham, P. L., Friedman, M., Garwood, R. J., Goswami, A., Hutchinson, J.
R., Jeffery, N. S., Johanson, Z., Lebrun, R., Martínez-Pérez, C., Marugán-Lobón, J., O’Higgins, P. M., Metscher, B., Orliac, M., Rowe, T. B., Rücklin, M., Sánchez-Villagra, M. R., Shubin, N. H., Smith, S. Y., Matthias Starck, J., Stringer, C., Summers, A. P., Sutton, M. D., Walsh, S. A., Weisbecker, V., Witmer, L. M., Wroe, S., Yin, Z., Rayfield, E. J., and Donoghue, P. C. J.: Open data and digital morphology, Proc. r. Soc., B 284, 20170194, 2017.

de Almeida, J. A. C.: Icnofósseis de macrobioerosã na Bacia da Paraíba (Cretáceo superior - Paleógeno), nordeste do Brasil, Unpublished PhD Thesis, Universidade Federal de Pernambucco, 2007.

de Blainville, H. M. D.: Mémoire sur les Bélemnites, considérées zoologiquement et géologiquement, Levrault, Paris, 1827.

De Vos, L., Rützler, K., Boury-Esnault, N., Donadey, C., and Vacelet, J.: Atlas of sponge morphology, Smithsionian Institute Press, Washington DC and London, 1991.

Emig, C. C.: British and other Phoronids, in: Synopses of the British fauna, edited by: Kermack, D. M. and Barnes, R. S. K., Academic Press, London, 13, 57 pp., 1979.

Emig, C. C.: The Biology of the Phoronida, Adv. Mar. Biol, 19, $1-89,1982$.

Emig, C. C.: Phylogenetic systematics in Phoronida (Lophophorata), Z. Zool. System. Evolut.-forsch., 23, 184-193, 1985.

Emig, C. C.: Fossil Phoronida and related ichnotaxa, Carnets de Géologie/Notebooks on Geology, Letter 2010/03 (CG2010_L03), 2010.

Emson, R. H.: The reaction of the sponge Cliona celata to applied stimuli, Comp. Biochem. Physiol., 18, 805-827, 1966.

Färber, C., Titschack, J., Schönberg, C. H. L., Ehrig, K., Boos, K., Baum, D., Illerhaus, B., Asgaard, U., Bromley, R. G., Freiwald, A., and Wisshak, M.: Long-term macrobioerosion in the Mediterranean Sea assessed by micro-computed tomography, Biogeosciences, 13, 3461-3474, https://doi.org/10.5194/bg-133461-2016, 2016.

Faulwetter, S., Vasileiadou, A., Kouratoras, M., Dailianis, T., and Arvanitidis, C.: Micro-computed tomography: Introducing new dimensions to taxonomy, ZooKeys, 263, 1-45, 2013.

Feldkamp, L. A., Davis, L. C., and Kress, J. W.: Practical conebeam algorithm, J. Opt. Soc. Am., A, 1, 612-619, 1984.

Fischer, P.: Recherches sur les éponges perforantes fossiles, Nouv. Arch. Mus. Hist. Nat. Paris, 4, 117-173, 1868.

Fromont, J.: Descriptions of species of the Haplosclerida (Porifera: Demospongiae) occurring in tropical waters of the Great Barrier Reef, The Beagle, Rec. Northern Terr. Mus. Arts and Sci., 10, 7-40, 1993.

Gewin, V.: All living things, online, Nature, 418, 362-363, 2002.

Girod, P. and Rösner, T.: Spurenfossilien (Ichnofossilien), in: Fossilien aus dem Campan von Hannover, edited by: Arbeitskreis Paläontologie Hannover, Hannover, 280-288, 2013.

Glaub, I.: Mikrobohrspuren in ausgewählten Ablagerungsräumen des europäischen Jura und der Unterkreide (Klassifikation und Palökologie), Courier Forschungsinstitut Senckenberg, 174, 1324, 1994.

Golubic, S., Brent, G., and LeCampion, T.: Scanning electron microscopy of endolithic algae and fungi using a multipurpose casting-embedding technique, Lethaia, 3, 203-209, 1970.

Gripp, K.: Polydora biforans n. sp. ein in Belemniten-Rostren bohrender Wurm der Kreide-Zeit, Meyniana, 17, 9-10, 1967. 
Häntzschel, W.: Trace fossils and problematica, in: Treatise on Invertebrate Paleontology, Part W - Miscellanea, edited by: Moore, R. C., Geological Society of America, Boulder and The University of Kansas Press, Lawrence, W177-245, 1962.

Häntzschel, W.: Trace fossils and problematica, in: Treatise on Invertebrate Paleontology, Part W - Miscellanea, Supplement 1, edited by: Moore, R. C., Geological Society of America, Boulder and The University of Kansas Press, Lawrence, 1975.

Hillmer, G. and Schulz, M.: Ableitung der Biologie und Ökologie eines Polychaeten der Oberkreide durch Analyse des Bohrganges Ramosulcichnus biforans (Gripp) nov. ichnogen., Mitteilungen aus dem Geologisch-Paläontologischen Institut der Universität Hamburg, 42, 5-24, 1973.

Hoffmann, R., Richter, D. K., Neuser, R. D., Jöns, N., Linzmeier, B. J., Lemanis, R. E., Fusseis, F., Xiao, X., and Immenhauser, A.: Evidence for a composite organic-inorganic fabric of belemnite rostra: implications for palaeoceanography and palaeoecology, Sedim. Geol., 341, 203-215, 2016.

Hofmann, K.: Die mikro-endolithischen Spurenfossilien der borealen Oberkreide Nordwest-Europas und ihre Faziesbeziehungen, Geol. Jb., A 136, 1-151, 1996.

Hutchings, P. A. and Peyrot-Clausade, M.: The distribution and abundance of boring species of polychaetes and sipunculans in coral substrates in French Polynesia, J. Exp. Mar. Biol. Ecol., 269, 101-121, 2002.

ICZN [International Commission for Zoological Nomenclature]: International Code of Zoological Nomenclature, adopted by the International Union of Biological Sciences, 4th ed., International Trust for Zoological Nomenclature, London, 1999.

Jagt, J. W. M.: The ichnofossil genera Radulichnus and Renichnus in the Maastrichtian of The Netherlands and Belgium. Bull. Inst. r. Soc. nat. Hist. Belg., Sci. Terre, 73, 175-184, 2003.

Knaust, D.: The ichnogenus Rhizocorallium: Classification, trace makers, palaeoenvironments and evolution, Earth-Sci. Rev., 126, 1-47, 2013.

Lautenschlager, S. and Rücklin, M.: Beyond the print - virtual paleontology in science publishing, outreach, and education, J. Paleontol., 88, 727-734, 2014.

Mägdefrau, K.: Über einige Bohrgänge aus dem unteren Muschelkalk von Jena, Palaeontol. Z., 14, 150-160, 1932.

Mägdefrau, K.: Lebensspuren fossiler "Bohr"-Organismen, Beiträge zur naturkundlichen Forschung in Südwestdeutschland, 2, 54-67, 1937.

Martinell, J. and Domènech, R.: Boring activity of Epibionts in an Early Holocene molluscan fauna of Spanish Catalunya, Acta Geol. Hisp., 16, 145-149, 1981.

Matsuyama, K., Titschack, J., Baum, D., and Freiwald, A.: Two new species of erect Bryozoa (Gymnolaemata: Cheilostomata) and the application of non-destructive imaging methods for quantitative taxonomy, Zootaxa, 4020, 81-100, 2015.

Mayoral, E.: Pennatichnus nov. icnogen.; Pinaceocladichnus nov. icnogen. e Iramena. Huellas de bioerosión debidas a Bryozoa perforantes (Ctenostomata, Plioceno inferior) en la Cuenca del Bajo Guadalquivir, Rev. Esp. Paleontol., 3, 13-22, 1988.

Morningstar, H.: Catalogue of type fossils in the Geological Museum at the Ohio State University, Ohio J. Sci., 24, 31-64, 1924.

Morris, J.: Palaeontological notes, Ann. Mag. Nat. Hist., Ser 2, 8, 85-90, 1851.
Neumann, C.: Vergleichende Paläoökologie von EchinidenGemeinschaften aus neritischen und hemipelagischen Ablagerungen der höheren Oberkreide Norddeutschland. Abstract, 70. Jahrestagung der Paläontologischen Gesellschaft, 87,2000

Neumann, C., Wisshak, M., and Bromley, R. G.: Boring a mobile domicile: an alternative to the conchicolous life habit, in: Current developments in bioerosion, edited by: Wisshak, M. and Tapanila, L., Springer, Heidelberg, 307-327, 2008.

Niebuhr, B.: Fazies-Differenzierungen und ihre Steuerungsfaktoren in der höheren Oberkreide von S-Niedersachsen/Sachsen-Anhalt (N-Deutschland), Berliner Geowiss. Abh., A 174, 1-131, 1995.

Niebuhr, B., Hiss, M., Kaplan, U., Tröger, K.-A., Voigt, S., Voigt, T., Wiese, F., and Wilmsen, M.: Lithostratigraphie der norddeutschen Oberkreide, Schriftenreihe der Deutschen Gesellschaft für Geowissenschaften, 55, 1-136, 2007.

Plewes, C. R.: Ichnotaxonomic studies of Jurassic endoliths, PhD Thesis, Aberystwyth, University of Wales, 1996.

Portlock, J. E.: Report on the geology of the County of Londonderry, and parts of Tyrone and Fermanagh, Her Majesty Stationary Office, Dublin, 1843.

Quenstedt, F. A.: Petrefactenkunde Deutschlands. Abtheilung 1. Band 1: Cephalopoden, Fues's, Leipzig, [text volume and atlas], 1849.

Radtke, G.: Die mikroendolithischen Spurenfossilien im Alt-Tertiär West-Europas und ihre palökologische Bedeutung, Courier Forschungsinstitut Senckenberg, 138, 1-185, 1991.

Radwański, A.: Remarks on the nature of belemnicolid borings Dendrina, Acta Geol. Pol., 22, 257-264, 1972.

Reis, O. M.: Beobachtungen über Schichtenfolge und Gesteinsausbildungen in der fränkischen Unteren und Mittleren Trias, Geognostische Jahreshefte, 22, 1-285, 1910.

Rice, M. E.: Possible boring structures of sipunculids, Am. Zool., 9, 803-812, 1969.

Rützler, K.: Bredin-Archbold-Smithsonian biological survey of Dominica: burrowing sponges, genus Siphonodictyon Bergquist, from the Caribbean, Smiths. Contr. Zool., 77, 1-37, 1971.

Rützler, K.: Family Clionaidae D'Orbigny, 1851, in: Systema Porifera: a guide to the classification of sponges, edited by: Hooper, N. A. and Van Soest, R. W. M., Kluwer Academic/Plenum Publishers, New York, 173-185, 2002.

Ruthensteiner, B. and Heß, M.: Embedding 3D models of biological specimens in PDF publications, Microscopy Res. Techniq., 71, 778-786, 2008.

Schönberg, C. H. L.: Bioeroding sponges common to the central Great Barrier Reef: descriptions of three new species, two new records, and additions to two previously described species, Senckenbergiana Marit., 30, 161-221, 2000.

Schönberg, C. H. L.: Self-cleaning surfaces in sponges, Mar. Biodiv., 45, 623-624, 2015.

Schönberg, C. H. L.: Happy relationships between marine sponges and sediments - a review and some observations from Australia, J. Mar. Biol. Assoc. U.K., 96, 493-514, 2016.

Schönberg, C. H. L. and Tapanila, L.: The bioeroding sponge Aka paratypica, a modern tracemaking analogue for the Paleozoic ichnogenus Entobia devonica, Ichnos, 13, 147-157, 2006.

Schönberg, C. H. L., Fang, J. K. H., and Carballo, J. L.: Bioeroding sponges and the future of coral reefs, in: Climate change, ocean 
acidification and sponges, edited by: Bell, J. J. and Carballo, J. L., Springer, Heidelberg, in press, 2017.

Shuler, E. W.: Dinosaur tracks mounted in the bandstand at Glen Rose, Texas, Field and Laboratory, 9, 9-13, 1935.

Stalling, D., Westerhoff, M., and Hege, H.-C.: Amira: a highly interactive system for visual data analysis, in: Visualization handbook, edited by: Hansen, C. D. and Johnson, C. R., ButterworthHeinemann, Burlington, 749-767, 2005.

Stephenson, L. W.: Large invertebrate fossils of the Woodbine Formation (Cenomanian) of Texas, U. S. Geol. Surv. Prof. Pap., 242, 1-226, 1952.

Strehlow, B. W., Jorgensen, D., Webster, N. S., Pineda, M. C., and Duckworth, A.: Using a thermistor flowmeter with attached video camera for monitoring sponge excurrent speed and oscular behavior, PeerJ, 4, e2761, https://doi.org/10.7717/peerj.2761, 2016.

Surlyk, F. and Birkelund, T.: An integrated stratigraphical study of fossil assemblages from the Maastrichtian white chalk of northwestern Europe, in: Concepts and methods of biostratigraphy, edited by: Kauffman, E. G. and Hazel, J. E., Dowden, Hutchinson \& Ross, Stroudsburg, 257-281, 1977.

Tapanila, L.: The medium is the message: imaging a complex microboring (Pyrodendrina cupra igen. n., isp n.) from the early Paleozoic of Anticosti Island, Canada, in: Current developments in bioerosion, edited by: Wisshak, M. and Tapanila, L., Springer, Heidelberg, 123-145, 2008.

Thomas, P. A.: Studies on Indian sponges: II. Two new species of siliceous sponges belonging to the genera Aka de Laubenfels and Damirina Burton, J. Mar. Biol. Assoc. India, 10, 250-254, 1968.

Voigt, E.: Endolithische Wurm-Tunnelbauten (Lapispecus cuniculus n.g.n.sp. und Dodecaceria [?] sp.) in Brandungsgeröllen der oberen Kreide im nördlichen Harzvorlande, Geol. Rundsch., 60, 355-380, 1970.

Voigt, E.: Fremdskulpturen an Steinkernen von PolychaetenBohrgängen aus der Maastrichter Tuffkreide, Palaeontol. Z., 45, 144-153, 1971.

Voigt, E.: Über Talpina ramosa v. Hagenow 1840, ein wahrscheinlich zu den Phoronidea gehöriger Bohrorganismus aus der Oberen Kreide, nebst Bemerkungen zu den übrigen bisher beschriebenen kretazischen "Talpina"-Arten, Nachrichten der Akademie der Wissenschaften zu Göttingen (II: Mathematischphysikalische Klasse), 7, 93-126, 1972.
Voigt, E.: Tunnelbaue rezenter und fossiler Phoronidea, Palaeontol. Z., 49, 135-167, 1975.

von Hagenow, F.: Monographie der Rügen'schen Kreideversteinerungen, II. Abtheilung: Radiarien und Annulaten nebst Nachträgen zur ersten Abtheilung, Neues Jahrbuch für Mineralogie, Geognosie, Geologie und Petrefaktenkunde, 7, 630-672, 1840.

Warme, J. E.: Traces and significance of marine borers, in: Trace Fossils, edited by: Crimes, T. P. and Harper, J. C., Geol. J., Spec. Issue, 3, 515-526, 1970.

Warme, J. E.: Borings as trace fossils, and the process of marine bioerosion, in: The study of trace fossils, edited by: Frey, R. W., Springer, New York, 181-227, 1975.

Warme, J. E. and Marshall, N. F.: Marine borers in calcareous terrigenous rocks of the Pacific coast, Am. Zool., 9, 765-774, 1969.

Williams, J. A. and Margolis, S. V.: Sipunculid burrows in coral reefs: evidence for chemical and mechanical excavations, Pac. Sci., 28, 357-359, 1974.

Wisshak, M.: Microbioerosion, in: Trace fossils as indicators of sedimentary environments, edited by: Knaust, D. and Bromley, R. G., Elsevier, Amsterdam, 213-243, 2012.

Wisshak, M.: Taming an ichnotaxonomical Pandora's box: Revision of dendritic and rosetted microborings (ichnofamily: Dendrinidae), European Journal of Taxonomy, in press, 2017.

Wisshak, M., Titschack, J., Kahl, W.-A., and Girod, P.: 3DPDFs and OBJ files of micro-CT scans, available at: https://doi.org/10.1594/PANGAEA.875121, 2017a.

Wisshak, M., Neumann, C., Knaust, D., and Reich, M.: Rediscovery of type material of the bioerosional trace fossil Talpina von Hagenow, 1840 and its ichnotaxonomical implications, Palaeontol. Z., 91, 127-135, 2017.

Wright, T. S.: Description of two tubicolar animals, Proc. r. Soc. Edinb., 1, 165-167, 1856.

Yahel, G., Eerkes-Medrano, D. I., and Leys, S. P.: Size independent selective filtration of ultraplankton by hexactinellid glass sponges, Aquat. Microbiol. Ecol., 45, 18-94, 2006. 